\title{
CAMA
}

Centre for Applied Macroeconomic Analysis

\section{Oil Curse, Economic Growth and Trade Openness}

\section{CAMA Working Paper 78/2019 October 2019}

\section{Monoj Kumar Majumder}

Tasmanian School of Business and Economics, University of Tasmania Department of Agricultural Economics, Sher-e-Bangla Agricultural University, Bangladesh

\section{Mala Raghavan}

Tasmanian School of Business and Economics, University of Tasmania

Centre for Applied Macroeconomic Analysis, ANU

\section{Joaquin Vespignani}

Tasmanian School of Business and Economics, University of Tasmania Centre for Applied Macroeconomic Analysis, ANU

\section{Abstract}

An important economic paradox that frequently arises in the economic literature is that countries with abundant natural resources are poor in terms of real gross domestic product per capita. This paradox, known as the 'resource curse', is contrary to the conventional intuition that natural resources help to improve economic growth and prosperity. Using panel data for 95 countries, this study revisits the resource curse paradox in terms of oil resources abundance for the period 1980-2017. In addition, the study examines the role of trade openness in influencing the relationship between oil abundance and economic growth. The study finds that trade openness is a possible avenue to reduce the resource curse. Trade openness allows countries to obtain competitive prices for their resources in the international market and access advanced technologies to extract resources more efficiently. Therefore, natural resource-rich economies can reduce the resource curse by opening themselves to international trade. 


\section{Keywords}

Oil rents, real GDP per capita, trade openness, dynamic panel data model

JEL Classification

E23, F13, Q43

Address for correspondence:

(E) cama.admin@anu.edu.au

ISSN 2206-0332

The Centre for Applied Macroeconomic Analysis in the Crawford School of Public Policy has been established to build strong links between professional macroeconomists. It provides a forum for quality macroeconomic research and discussion of policy issues between academia, government and the private sector.

The Crawford School of Public Policy is the Australian National University's public policy school, serving and influencing Australia, Asia and the Pacific through advanced policy research, graduate and executive education, and policy impact. 


\title{
Oil Curse, Economic Growth and Trade Openness
}

\author{
Joaquin Vespignani $^{\mathrm{a}, \mathrm{b}}$, Mala Raghavan ${ }^{\mathrm{a}, \mathrm{b}}$, Monoj Kumar Majumder a,c* \\ ${ }^{\text {a }}$ Tasmanian School of Business and Economics, University of Tasmania, Australia \\ ${ }^{\mathrm{b}}$ Centre for Applied Macroeconomic Analysis, Australian National University, Australia \\ ${ }^{c}$ Department of Agricultural Economics, Sher-e-Bangla Agricultural University, Bangladesh
}

\begin{abstract}
An important economic paradox that frequently arises in the economic literature is that countries with abundant natural resources are poor in terms of real gross domestic product per capita. This paradox, known as the 'resource curse', is contrary to the conventional intuition that natural resources help to improve economic growth and prosperity. Using panel data for 95 countries, this study revisits the resource curse paradox in terms of oil resources abundance for the period 1980-2017. In addition, the study examines the role of trade openness in influencing the relationship between oil abundance and economic growth. The study finds that trade openness is a possible avenue to reduce the resource curse. Trade openness allows countries to obtain competitive prices for their resources in the international market and access advanced technologies to extract resources more efficiently. Therefore, natural resource-rich economies can reduce the resource curse by opening themselves to international trade.
\end{abstract}

Keywords: Oil rents, real GDP per capita, trade openness, dynamic panel data model JEL classification: E23, F13, Q43

\footnotetext{
${ }^{*}$ Corresponding author.

E-mail addresses: Joaquin.vespignani@utas.edu.au (J. L. Vespignani), mala.raghavan@utas.edu.au (M. Raghavan), monojkumar.majumder@utas.edu.au (M. K. Majumder)
}

\section{Introduction}


The conventional intuition is that natural resources help to increase a country's economic growth. Contrary to this, the literature reports that countries rich in natural resources tend to have lower real gross domestic product (GDP) per capita than resource-poor countries-a paradox known as the 'resource curse' [see, e.g., Auty (1993), Sachs and Warner (1995), Gylfason (2000) and Van der Ploeg (2011)]. ${ }^{1}$ For example, oil-rich countries such as Venezuela, Nigeria and the Republic of the Congo are poor in terms of real GDP per capita, while resource-poor countries such as Singapore, South Korea and Hong Kong have very high real GDP per capita. ${ }^{2}$ The literature identifies several factors that explain this paradox such as poor institutional quality, political rent-seeking, commodity price volatility and lack of diversification. However, several other factors remain unexplored. This study examines a country's trade openness as a channel that may influence the resource curse. ${ }^{3}$ The idea that trade openness increases economic growth is well known; however the role of trade openness in reducing the resource curse is yet to be explored.

Trade openness increases real GDP per capita in a resource-rich country in different ways. Our hypothesis is that increased trade helps to lessen the resource curse problem by reallocating resources more efficiently. It provides countries access to the international market and higher prices for their products. This access to international prices increases the country's income and real GDP per capita. Trade openness also makes available opportunities to use advanced technologies for more efficient extraction of natural resources. With the use of new technologies, natural resource-rich countries can produce intermediate and final goods from primary goods and earn more profits. Trade openness helps to modernise the full economy by improving other related sectors such as roads and transport systems (Pedersen 2000), financial

\footnotetext{
${ }^{1}$ The term 'resource curse' was first coined by Auty (1993) to explain the negative relationship between resource dependency and economic growth.

${ }^{2}$ Note that this is not true for all countries. For example, oil-rich countries such as Norway, Saudi Arabia and Qatar have high GDP per capita.

${ }^{3}$ Trade openness is the sum of export and import of the goods and services measured as a percentage of GDP.
} 
sectors (Braun \& Raddatz 2008) and bureaucratic systems (Dutt 2009). Overall, trade openness plays a crucial role in converting natural resources into a blessing rather a curse. Figure 1 shows the relationship between real GDP per capita and oil rent (\% of GDP) for the period 19802017.4

Figure 1: Relation between real GDP per capita and oil rent (\% of GDP)

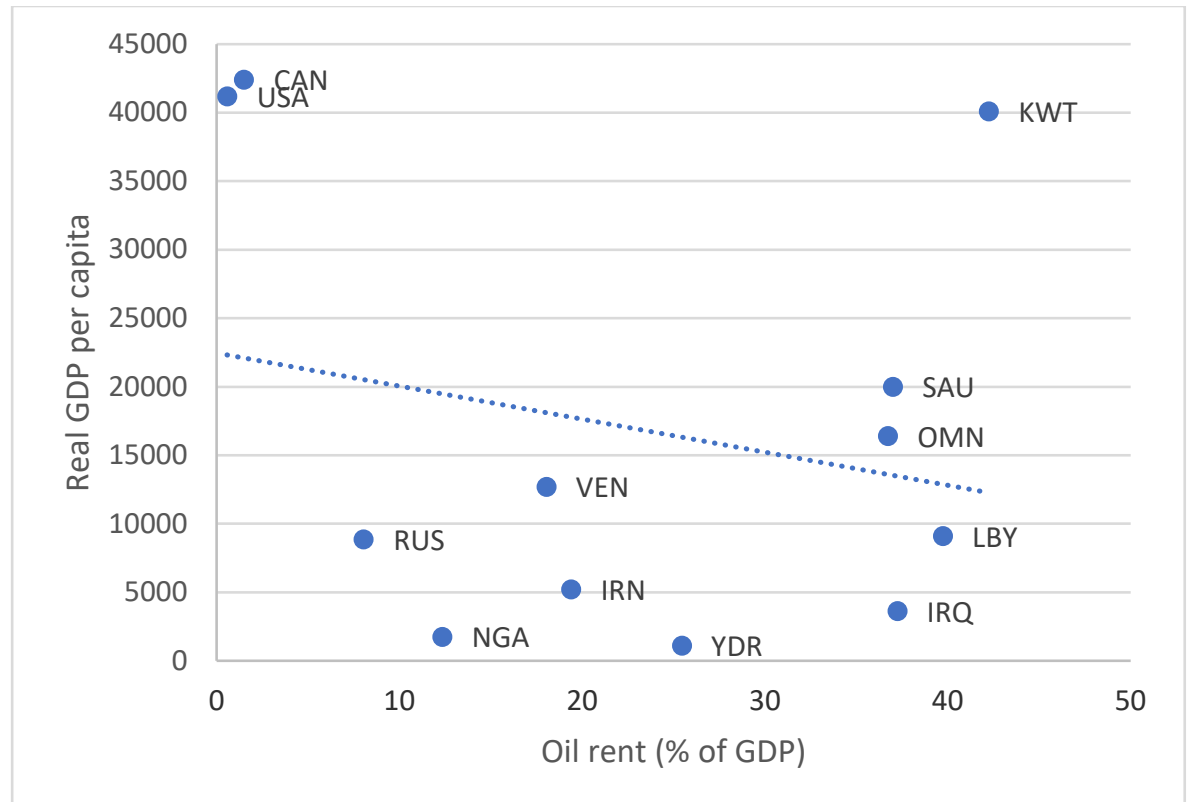

Source: Author's calculations based on World Bank (2019).

Despite the positive impact of trade openness on economic growth and development, it was not considered comprehensively when studying the resource curse, aside from a brief discussion in a few studies. ${ }^{5}$ Arezki and Van der Ploeg (2011) investigate the role of trade and institutions in reducing the resource curse and find that the resource curse becomes weaker in countries with a high degree of trade openness. In their seminal study, Sachs and Warner (1995) also find that trade openness improves economic growth by reducing the resource curse. However, these studies are based on cross-section growth models where the average growth

\footnotetext{
${ }^{4}$ In Figure 1, we use the average data of real GDP per capita and oil rent (\% of GDP) for countries with high oil reserves.

${ }^{5}$ Throughout this study, we use change in real GDP per capita and economic growth interchangeably.
} 
over recent decades is regressed on a measure of resource abundance and a selection of control variables.

In this study, we use a panel data framework to investigate the impact of trade openness on the resource curse. ${ }^{6}$ To the best of our knowledge, this is the first study to explore the relationship between the resource curse and trade openness in a panel data framework (rather than cross-sectional long-term perspective). ${ }^{7}$

This study uses an unbalanced dynamic panel data model that covers 95 countries for the period 1980-2017. Countries and periods are based on data availability from the World Bank (WB) and International Monetary Fund (IMF). We use the data for the full sample period (1980-2017) and then split the sample period into two subsample periods: 1980-1994 [before the World Trade Organization (WTO)] and 1995-2017 (after the WTO). We assume that the commencement of the WTO in 1995 contributed to significant increases in international trade and that increased trade helps to lessen the resource curse by more efficiently reallocating resources. Moreover, many countries reduced their trade tariffs under the WTO agreements which has helped to boost international trade during the last two decades. ${ }^{8}$ For example, China abolished non-tariff barriers and reduced tariffs in the manufacturing sector after it joined the WTO in 2001. This significantly increased the demand for metals such as copper, aluminium, and steel (Coates \& Luu 2012). This increased demand probably had an exogenous impact on the growth of other countries. For example, Andersen et al. (2014) empirically found that

\footnotetext{
${ }^{6}$ Panel data usually gives researchers a large number of data points, increasing the degrees of freedom and reducing the collinearity among explanatory variables, thus improving the efficiency of econometric estimates (Hsiao 2014). Moreover, the combined panel data matrix set consists of a time series for each cross-sectional member in the data set and offer a variety of estimation methods (Asteriou \& Hall 2015).

${ }^{7}$ Few studies use panel data models to discuss the resource curse hypothesis. By using a panel data model consisting of 56 countries from 1972-2000, Mavrotas, Murshed and Torres (2011) found that point resource dependence harms economic growth in developing countries. Similarly, Goderis (2008) found the existence of resource curse by using panel data for 130 countries for the period 1963-2003.

${ }^{8}$ The WTO is an intergovernmental organisation that deals with the regulation of trade in goods, services and intellectual property between participating countries by providing a framework for negotiating trade agreements and a dispute resolution process. Subramanian and Wei (2007) argue that the WTO contributed to 120 per cent more trade in 2000, valued about US\$8 trillion.
} 
China's accession to the WTO contributed to improving the growth rate in sub-Saharan African countries.

This study focuses on oil as a natural resource because it is a highly tradeable commodity. As oil price is directly linked to the production process, it may have a significant impact on inflation, employment and output (Guo \& Kliesen 2005). Moreover, point-source resources such as oil are more prone to rent-seeking that leads to resource curse (Isham et al. 2005; Boschini, Pettersson \& Roine 2007). ${ }^{9}$ In this study, we use oil rent (\% of GDP) as a measure of natural resource abundance. ${ }^{10}$ Although our study finds the existence of the resource curse, trade openness significantly decreases the resource curse problem, especially after the introduction of the WTO.

This study contributes to the literature in the following ways. First, to the best of our knowledge, no previous studies have examined trade openness as a transmission channel for reducing the resource curse by using dynamic panel data models. Second, using panel data allows us to evaluate the effect of trade openness over time and, particularly, the impact of the dramatic changes that followed the commencement of the WTO. Finally, the time dimension of the panel data allows us to include periods of important recent fluctuations such as the global financial crisis and European sovereign debt crisis.

The study proceeds as follows. Section 2 provides an overview of the resource curse literature. Section 3 describes the conceptual framework of the importance of trade. The

\footnotetext{
${ }^{9}$ A point-source resource is a resource concentrated in a single identifiable location (i.e., not diffused in wide areas).

${ }^{10}$ Following Bjorvatn, Farzanegan and Schneider (2012); Arezki and Brückner (2011); Bhattacharyya and Hodler (2010); and Collier and Hoeffler (2005), we use oil rents (\% of GDP) as a proxy of natural resource abundance. Rents are basically net profits from resource extraction, defined as the value of the product minus total cost of production. Rents measure the value of natural resources for a country. More precisely, they provide a less ambiguous measure of resource dependence compared with those previously used such as primary commodity exports, oil exports and reserves. The rent data tells us the value of the resource in the open market relative to the productivity of the economy, and, indirectly, the value of capturing them (De Soysa \& Neumayer 2007). For robustness, we use the natural resource rent (\% of GDP). We define 'abundance' as the resource contributing a large share of a country's GDP.
} 
methodology of this study is described in Section 4. Section 5 describes the data and description of the variables and Section 6 presents the empirical results from panel data estimations. Section 7 provides our conclusions and directions for future studies.

\section{Overview of the resource curse literature}

To study the role of natural resources in economic growth, it is essential to investigate the mechanisms that link endowments of natural resources to poor economic performance. In the literature, various economic and political reasons have been discussed for the failure to transform natural resources into economic growth including the 'Dutch disease', political rentseeking and corruption, poor institutional quality, commodity price volatility and lack of diversification. We discuss these factors in detail in the following sections.

\subsection{The Dutch disease}

One of the most common economic reasons suggested for the resource curse is popularly known as the Dutch disease. In most resource-rich countries, sectors other than resources are likely to suffer from a real appreciation of the national currency due to natural resource earnings, in part, being absorbed by the domestic non-tradeable sectors [see, e.g., Corden and Neary (1982), Sachs and Warner (1995), Papyrakis and Gerlagh (2007) and Iimi (2007)]. ${ }^{11}$ This results in exports from the non-resources sectors (usually manufacturing) become more expensive relative to the world market, thus making those sectors less competitive. Consequently, total national income is reduced, ultimately causing economic growth to slow. This mechanism is known as the 'spending effect' (see Figure 2).

\footnotetext{
${ }^{11}$ Corden and Neary (1982) and Corden (1984) first developed the Dutch disease model. Iimi (2007) described Dutch disease as the most prominent channel of the resource curse. Sachs and Warner (1995) argued that the Dutch disease is responsible for the slow economic growth of resource-rich African countries.
} 
Figure 2: The spending effect in the 'Dutch disease'

\begin{tabular}{|c|c|c|c|c|}
\hline $\begin{array}{l}\text { Natural resource revenue } \\
\text { boom }\end{array}$ & $\Rightarrow$ & $\begin{array}{l}\text { Inflation and real exchange } \\
\text { rate appreciation }\end{array}$ & $\Longrightarrow$ & $\begin{array}{l}\text { Decrease in world demand } \\
\text { for country’s non-resource } \\
\text { products. }\end{array}$ \\
\hline Increase in resource rents & $\Longrightarrow$ & $\begin{array}{l}\text { Price of manufacturing } \\
\text { products increases making } \\
\text { those products expensive } \\
\text { relative to world market } \\
\text { price }\end{array}$ & $\Rightarrow$ & $\begin{array}{l}\text { Production decline in other } \\
\text { sectors those are unrelated to } \\
\text { the resources. Consequently, } \\
\text { income and employment } \\
\text { decrease. }\end{array}$ \\
\hline
\end{tabular}

Source: Badeeb, Lean and Clark (2017).

\subsection{Political rent-seeking and corruption}

According to Gylfason (2001), Lam and Wantchekon (2003), Hodler (2006) and Deacon and Rode (2015), the powerful political elites of resource-rich countries can control revenues from natural resources. These elites tend to distribute the windfall revenues for the benefit of their own existing business and personal networks, instead of investing them in the development sectors. This rent-seeking behaviour increases income inequality which hampers sustainable economic growth. Moreover, such revenue windfalls are considered to be one of the major reasons for the increasing conflict between stakeholders such as taxpayers, politicians, local tribes and developers (Sala-i-Martin \& Subramanian 2013). Such conflict discourages both domestic and international investment which also leads to lower economic growth.

\subsection{Poor institutional quality}

Another reason for the resource curse - and closely related to political rent-seeking —is poor institutional quality. According to Mehlum, Moene and Torvik (2006) and Mavrotas, Murshed and Torres (2011), a country’s institutional quality plays an important role in determining whether an abundance of natural resources is a blessing or a curse. It is argued that high levels of growth in resource-rich countries are due to the way in which rents from natural resources are distributed through existing institutional arrangements. If institutional quality is good, a generous endowment of natural resource is a blessing. Mehlum, Moene and Torvik (2006); 
Torvik (2009); and Sarmidi, Hook Law and Jafari (2014) argue that the adverse effect of natural resource abundance on economic growth will be dissipated if institutional quality is improved.

\subsection{Commodity price volatility}

Commodity price volatility is another important channel for the resource curse. According to the Bellemare, Barrett and Just (2013); Dwyer, Gardner and Williams (2011); Tujula and Wolswijk (2004); and Dehn (2000), commodity price volatility generates uncertainty in the economy, delays stability in the budget, undermines the predictability of economic planning and potentially contributes to lower economic growth. Moreover, Catão and Kapur (2004) argue that during volatile periods countries need more international borrowing to smooth consumption. Moreover, countries in this situation can expect to face stringent constraints on their borrowing capacity since financial markets will not only be aware of the default risk that volatility itself generates but will also be mindful that aggregate consumption and real investment decrease in times of commodity price volatility. These dynamics will likely lead to lower economic growth. ${ }^{12}$

\subsection{Lack of diversification}

Another reason for the resource curse is the lack of economic diversification in countries abundant in natural resources. The major share of export earrings in these countries is generated from just one or a few resources. This leads to economic vulnerability from exogenous shocks and results in slow economic growth (De Ferranti et al. 2002). Moreover, the natural resource sector is generally capital intensive and location specific (Masten \& Crocker 1985). Consequently, natural resource development brings few positive externalities to forward and

\footnotetext{
${ }^{12}$ According to Başkaya, Hülagü and Küçük (2013); Salim and Rafiq (2011); and Guo and Kliesen (2005), consumer demand decreases due to the adoption of a precautionary savings mindset by consumers who are worried and uncertain about future income and unemployment levels as they are fearful that these levels may be adversely impacted during a period of commodity price volatility. Consequently, real investment decreases during periods of price volatility (Masih, Peters \& De Mello 2011; Henriques \& Sadorsky 2011; Guo \& Kliesen 2005; Bredin \& Fountas 2005).
} 
backward industries (Sachs \& Warner 1995). Therefore, the learning-by-doing effect is not expected to be powerful in these economies.

There is considerable literature on the above-mentioned transmission channels that give rise to the resource curse, but scant discussion about the dynamics associated with trade openness. Therefore, this study, which investigates the role of trade openness using panel data models, brings a new dimension to the resource curse literature.

\section{Conceptual framework: Importance of trade in resource-rich countries}

The uneven geographical distribution of resource endowment between countries plays a critically important part in explaining the significance of trade openness. Most of the world's natural resources are concentrated in a relatively small number of countries, while many countries have limited or no natural resources. For example, about 90 per cent of the world's proven oil reserves are in just 13 countries (BP 2017). ${ }^{13}$ Consequently, international trade plays a significant role in reducing the disparity in natural resource endowment of countries by allowing resources to move from areas of excess supply to areas of excess demand. Moreover, due to the excessive fixed costs in extracting the resources, large-scale extraction is required to achieve economies of scale. Large-scale production is only beneficial if there is a large market for exports of that resource. Overall, international trade is associated with a more efficient allocation of natural resources that leads to an increase in social welfare (Cho \& Diaz 2011).

Another important feature of natural resources is the dominant position of this sector in national economies. Many of resource-rich countries tend to rely on a narrow range of export products. Figure 3 shows the value of export product concentration index (PCI) of different

\footnotetext{
${ }^{13}$ The Middle East countries (Saudi Arabia, Iran, Iraq, Kuwait, Syria, United Arab Emirate, Qatar, Yemen and Oman) contain about 48 per cent of the world's total oil reserve, and Venezuela contains nearly 18 per cent as of 2016. The distribution of other fuels is also concentrated in a very small number of countries. For example, 10 countries possess 80 per cent of global natural gas reserves in 2016, and just nine countries have 90 per cent of the world's coal reserves.
} 
countries along with shares of natural resources in total merchandise exports for selected economies. ${ }^{14}$ The PCI is based on the number of products in the Standard International Trade Classification (SITC) at the three-digit level that exceeds 0.3 per cent of a given country's exports collected from the United Nations Conference on Trade and Development (UNCTAD).

Figure 3: Dominance of fuel resource exports

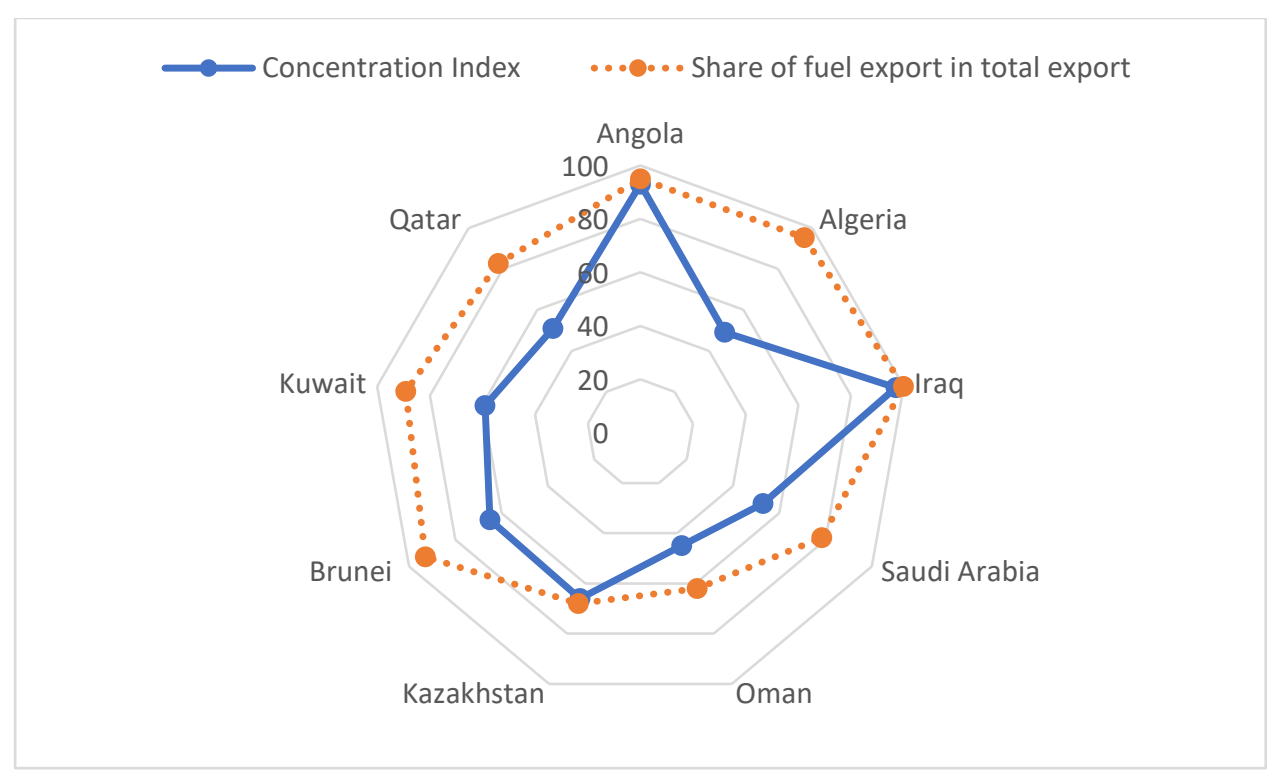

Source: Author's calculation based on UNCTAD (2016) and WB (2019).

From Figure 3, we can observe that the share of fuel in Kuwait, Brunei, Iraq and Angola is about 100 per cent of total merchandise exports by 2015. With very few exceptions, countries with a high concentration index also have a high share of fuel resources in their total merchandise exports. The dominance of natural resources in exports follows the hypothesis of comparative advantage theory arguing that countries will specialise in the production of goods where they have a comparative advantage and export them in exchange for other products. This

\footnotetext{
14 The PCI shows to what extent exports and imports of individual countries or country groups are concentrated on several products rather than being distributed homogeneously among products. It is measured as:

PCI $=\sqrt{\frac{\sum_{i=1}^{n} \frac{\left(x_{i, j}\right)^{2}}{x_{j}}-\sqrt{1 / n}}{1-\sqrt{1 / n}}} \times 100$

where, $x_{i, j}$ is the value of exports of products $i$ from economy $j$ and $n$ is the number of product groups according to SITC, Revision 3, at the three-digit level.
} 
is a direct implication of the Heckscher-Ohlin model which proposes that countries export what they can produce.

Overall, the above-described two characteristics of natural resources explain the importance of international trade to the efficient distribution of natural resources. As the government's revenue in resource-rich countries depends on one or few resources, if there are trade barriers then total revenue will decrease, causing slower economic growth. For example, Iran's government revenue and economic growth largely depend on the export of crude oil. However, due to some international restrictions, Iran cannot produce and sell oil at the optimum level and, thus, is forced to sell in the domestic market at a lower price. Consequently, Iran loses revenue, hampering economic growth. In general, economic growth largely depends on trade openness, especially for resource-rich economies.

\section{Methodology}

To explore the impact of oil rent (\% of GDP) on economic growth, we use the cross-section and period fixed effect model (combined model). However, other five-panel data estimation models-pooled least square (PLS) model, cross-section fixed effect model, cross-section random effect model, period fixed effect model, period random effect model—are also considered for robustness. ${ }^{15}$ The combined model allows us to eliminate bias arising from both unobservable variables that differ over time and across countries. For example, real GDP, trade and oil rent will differ between countries due to their differing geographies, natural endowments, political and cultural systems and other basic factors. These variables, however, do not differ over time. On the other hand, technological development or international agreements can change productivity growth globally which increases output over time. Period fixed effect model removes the effect of those country-invariant characteristics. Consequently,

\footnotetext{
15 These models are described in Appendix 2.
} 
the combined fixed effect model removes the effect of those time-invariant and cross-section invariant characteristics from the model so that we can assess the net impact of oil rent (\% of GDP) on economic growth. We adopt the following combined model to examine the impact of oil rent on economic growth:

$$
\begin{aligned}
& \Delta L G D P_{i, t}=\beta_{0 i}+\beta_{0 t}+\beta_{1} \Delta L G D P_{i, t-1}+\beta_{2} L O I L_{i, t}+\beta_{3} L U N_{i, t}+\beta_{4} L F D I_{i, t}+ \\
& \beta_{5} L C A B_{i, t}+\beta_{6} L M I_{i, t}+\beta_{7} L M O R_{i, t}+\beta_{8} L T_{i, t}+\beta_{9} L T_{i, t} * L O I L_{i, t}+\varepsilon_{i, t}
\end{aligned}
$$

Where $\Delta L G D P_{i, t}$ is the change in log of real GDP per capita; $\Delta L G D P_{i, t-1}$ represents the lag in the change in log of real GDP per capita; $L O I L_{i, t}$ indicates the log in oil rent (\% of GDP); $L U N_{i, t}, L F D I_{i, t}, L C A B_{i, t}$ and $L M I_{i, t}$ indicate log in unemployment rate (\% of total force), log in foreign direct investment (\% of GDP), log in current account balance (\% of GDP) and log in military expense (\% of GDP) respectively; $L M O R_{i, t}$ is the log of the infant mortality rate (per 1,000 live births); and $L T_{i, t}$ represents the log of trade openness (\% of GDP). A detailed description of the variables included in equation (1) is presented in Table A1 in Appendix 1.

The subscripts $i$ and $t$ denote country and period respectively. $\beta_{0 i}$ and $\beta_{0 t}$ are the unobserved time-invariant and country-invariant individual effect respectively and the idiosyncratic disturbance term is denoted by $\varepsilon_{i, t}$. By using lag dependent variable, we capture autocorrelation in the model. In this study, we also include an interaction term in equation (1), denoted by $L T_{i, t} * L O I L_{i, t}$, to examine the hypothesis that trade openness significantly reduces the resource curse. In equation (1), we use estimates for the full sample period (1980-2017) and two subsample periods (1980-1994 and 1995-2017) to allow us to examine the hypothesis that the WTO impacts the resource curse. We also estimate equation (1) for the alternative measures of trade openness [exports (\% of GDP), imports (\% of GDP)] and natural resource rents (\% of GDP). 


\section{Data and description of the variables}

In this section, we discuss the definition of the variables and sources of the data. We also discuss the characteristics of the data such as unit root, descriptive statistics and correlation matrix of the variables.

\subsection{The data}

To estimate the models, this study employs an unbalanced annual panel data dataset for 95 countries covering the period 1980-2017, where the countries and period included are determined by data availability. ${ }^{16}$ The data for real GDP per capita, oil rent, foreign direct investment, current account balance, military expense, infant mortality rate and trade openness are collected from the World Development Indicator (WDI) of the WB. Unemployment rate data are collected from the World Economic Outlook of the IMF.

\subsection{Unit root test, descriptive statistics and correlation matrix}

We estimate the unit root to test the stationary for all variables by using the Augmented DuckyFuller (ADF) and the Phillips-Perron (PP) test. The stationary variable is characterised by having a constant mean and variance over time, and the covariance between two values in the series depends on the length of the time between the two values, but not on the actual times when the value is observed. With the exception of real GDP, all variables included in the model are stationary at $p=0.05$. The $p$-value of log real GDP is $>0.05$, indicating that this variable is not stationary. To make the series stationary, we take the first difference of this series. The results of the unit root, descriptive statistics and correlation matrix are presented in Tables A3, A4 and A5 respectively in Appendix 1.

\footnotetext{
${ }^{16}$ List of 95 countries are documented in Table A2 in Appendix 1.
} 


\section{Results and discussion}

In this section, we describe all empirical results estimated by six estimation methods-PLS model, cross-section fixed effect model, cross-section random effect model, period fixed effect model, period random effect model, and combined fixed effect model. In Section 6.1, we describe the estimated coefficients for the full sample period (1980-2017) and two subsample periods (1980-1994 and 1995-2017) estimated with the combined fixed effect model.

\subsection{Main results}

Table 1 reports the results. In this section, we only discuss the coefficient of the variables of interest—log in oil rent, log in trade openness and the interaction term between log in oil rent and log in trade openness. The coefficient of log in oil rent is negative, indicating that log in change of real GDP per capita decreases with the increase of log in oil rent and the estimated elasticity is -0.04 (see column 1 in Table 1). All other things being equal, a one per cent increase in log in oil rent is associated with a decrease in change in real GDP per capita of over 0.04 per cent. This negative association between growth in real GDP per capita and oil rent is evidence of the resource curse.

The positive coefficient of log in trade openness indicates that trade openness positively affects growth in real GDP per capita. The coefficient of the interaction term between log in trade openness and log in oil rent is also positive, indicating that opening to trade reduces the negative impact of log in oil rent on log in change of real GDP per capita. These results are significant $(p=0.01)$ and consistent with different time and country fixed effect and random effect models. The growth impact of a marginal increase in oil rent implied from equation (1) is:

$$
\frac{d\left(\Delta L G D P_{i, t}\right)}{d\left(L O I L_{i, t}\right)}=-0.04+0.01(\text { trade openness })
$$


We see that the resource curse is weaker where there is a higher level of trade openness. The coefficient of oil rent is -0.04 , but when we add the value of interaction term the value of the coefficient becomes smaller $(-0.04+0.01=-0.03<-0.04)$. Statistically, we can observe that resource curse decreases by $25 \%$ with the opening to trade. In the case of cross-section fixed effect model (column 3 in Table 1), the size of the coefficients of oil rent, trade openness and interaction term are similar to the combined model. However, the size of the coefficients is much smaller in the PLS and random effect models (columns 2, and 4 in Table 1). One plausible reason is that in the PLS and random effect models, the unobservable variables are assumed uncorrelated with all observed variables. As a result, the size of the coefficient is smaller than the combined fixed effect model $(-0.02)$. There are some major differences in the coefficients for the combined fixed effect and random effect models, which might reflect the importance of omitted variable bias in the latter. In the period fixed effect and period random effect models, the size of the coefficient is smaller than the cross-section fixed effect and the combined fixed effect models, indicating that country-invariant unobservable variables such as different agreements and laws are not correlated with the observed variables (see columns 5 and 6 in Table 1). 
Table 1: Change in real GDP per capita and oil rent (\% of GDP) in sample period (19802017).

\begin{tabular}{|c|c|c|c|c|c|c|}
\hline \multirow{4}{*}{$\Delta L G D P_{i, t-1}$} & \multicolumn{6}{|c|}{ Dependent variable: $\Delta L G D P_{i, t}$} \\
\hline & $\begin{array}{c}\text { Cross-section } \\
\text { and period fixed } \\
(1)\end{array}$ & $\begin{array}{l}\text { PLS } \\
(2)\end{array}$ & $\begin{array}{l}\text { Cross-section } \\
\text { fixed } \\
\text { (3) }\end{array}$ & $\begin{array}{l}\text { Cross-section } \\
\text { random } \\
(4)\end{array}$ & $\begin{array}{l}\text { Period } \\
\text { fixed } \\
(5)\end{array}$ & $\begin{array}{l}\text { Period } \\
\text { random } \\
(6)\end{array}$ \\
\hline & $0.40 * * *$ & $0.46^{* * *}$ & $0.36^{* * *}$ & $0.46^{* * *}$ & $0.51 * * *$ & $0.51 * * *$ \\
\hline & $(0.02)$ & $(0.02)$ & $(0.01)$ & $(0.01)$ & $(0.01)$ & $(0.01)$ \\
\hline & {$[0.03]$} & {$[0.03]$} & {$[0.03]$} & {$[0.03]$} & {$[0.03]$} & {$[0.03]$} \\
\hline \multirow{3}{*}{$L O I L_{i, t}$} & $-0.04 * * *$ & $-0.02 * * *$ & $-0.04 * * *$ & $-0.02 * * *$ & $-0.01^{* * *}$ & $-0.01 * * *$ \\
\hline & $(0.01)$ & $(0.007)$ & $(0.01)$ & $(0.006)$ & $(0.006)$ & $(0.006)$ \\
\hline & {$[0.01]$} & [0.01] & {$[0.01]$} & {$[0.01]$} & [0.009] & [0.009] \\
\hline \multirow{3}{*}{$L U N_{i, t}$} & -0.0007 & 0.0008 & -0.0008 & 0.0008 & 0.0001 & 0.0003 \\
\hline & $(0.001)$ & $(0.001)$ & $(0.001)$ & $(0.001)$ & $(0.0009)$ & $(0.0009)$ \\
\hline & {$[0.003]$} & {$[0.001]$} & {$[0.003]$} & {$[0.001]$} & {$[0.001]$} & {$[0.001]$} \\
\hline \multirow[t]{3}{*}{$L F D I_{i, t}$} & -0.002 & 0.002 & 0.005 & 0.002 & -0.003 & -0.003 \\
\hline & $(0.005)$ & $(0.005)$ & $(0.006)$ & $(0.005)$ & $(0.005)$ & $(0.005)$ \\
\hline & {$[0.004]$} & [0.004] & [0.004] & [0.004] & [0.004] & {$[0.004]$} \\
\hline \multirow[t]{3}{*}{$L C A B_{i, t}$} & $-0.08 * *$ & $-0.04 *$ & $-0.05^{*}$ & $-0.04 *$ & $-0.06 * *$ & $-0.05 * *$ \\
\hline & $(0.03)$ & $(0.02)$ & $(0.03)$ & $(0.02)$ & $(0.02)$ & $(0.02)$ \\
\hline & {$[0.04]$} & [0.03] & [0.04] & [0.03] & [0.03] & [0.03] \\
\hline \multirow[t]{3}{*}{$L M I_{i, t}$} & $-0.01 * * *$ & $-0.002 *$ & $-0.01 * * *$ & $-0.002 *$ & -0.001 & -0.001 \\
\hline & $(0.003)$ & $(0.001)$ & $(0.003)$ & $(0.001)$ & $(0.001)$ & $(0.001)$ \\
\hline & {$[0.004]$} & {$[0.001]$} & {$[0.004]$} & [0.001] & [0.001] & {$[0.001]$} \\
\hline \multirow[t]{3}{*}{$L M O R_{i, t}$} & $0.01 * * *$ & $0.002 * * *$ & $0.01 * * *$ & $0.002 * * *$ & $0.001 * *$ & $0.001 * *$ \\
\hline & $(0.004)$ & $(0.0008)$ & $(0.002)$ & $(0.0008)$ & $(0.0008)$ & $(0.0008)$ \\
\hline & [0.004] & {$[0.001]$} & [0.002] & {$[0.001]$} & [0.0009] & {$[0.009]$} \\
\hline \multirow[t]{3}{*}{$L T_{i, t}$} & $0.009 * *$ & $0.003^{* *}$ & $0.01 * * *$ & $0.003 * * *$ & $0.002 * *$ & $0.002 * *$ \\
\hline & $(0.003)$ & $(0.001)$ & $(0.004)$ & $(0.001)$ & $(0.001)$ & $(0.001)$ \\
\hline & {$[0.004]$} & {$[0.001]$} & {$[0.004]$} & {$[0.001]$} & {$[0.001]$} & {$[0.001]$} \\
\hline \multirow{3}{*}{$L T_{i, t}{ }^{*} L O I L_{i, t}$} & $0.01 * * *$ & $0.005 * * *$ & $0.01 * * *$ & $0.005^{* * *}$ & $0.004^{* * *}$ & $0.004 * * *$ \\
\hline & $(0.002)$ & $(0.001)$ & $(0.003)$ & $(0.001)$ & $(0.001)$ & $(0.001)$ \\
\hline & {$[0.003]$} & {$[0.002]$} & {$[0.004]$} & {$[0.002]$} & {$[0.002]$} & {$[0.002]$} \\
\hline $\mathrm{R}^{2}$ & 0.48 & 0.26 & 0.33 & 0.26 & 0.42 & 0.30 \\
\hline Adjusted $\mathrm{R}^{2}$ & 0.44 & 0.26 & 0.30 & 0.26 & 0.41 & 0.30 \\
\hline Periods & 38 & 38 & 38 & 38 & 38 & 38 \\
\hline Countries & 95 & 95 & 95 & 95 & 95 & 95 \\
\hline Observations & 2,499 & 2,499 & 2,499 & 2,499 & 2,499 & 2,499 \\
\hline
\end{tabular}

Note: Standard errors are presented below the corresponding coefficients in the bracket. ***, ** and * indicate the significance at the $10 \%, 5 \%$, and $1 \%$ level respectively. Cluster standard errors are presented in square brackets.

To investigate the impact of the WTO, we split our full sample period (1980-2017) into two subsample periods (1980-1994 and 1995-2017). We hypothesise that the introduction of the WTO on 1 January 1995 may have significantly increased international trade and, thereby, 
reduced the resource curse. ${ }^{17}$ According to Goldstein, Rivers and Tomz (2007) and Tomz, Goldstein and Rivers (2007), participation in the WTO substantially increased trade for the whole world. Moreover, Nicita, Olarreaga and Silva (2013) demonstrate that the average country would face a 32 per cent increase in tariffs on their exports in the absence of the WTO.

In Table 2, we present the empirical findings on the nexus between real GDP per capita and oil rent for the two subsample periods (1980-1994 in column 1 and 1995-2017 in column 2) and compare these with the full sample period. The coefficient of log in oil rent in the period 1980-1994 is negative, and the estimated elasticity is -0.05 (column 1 in Table 2). All other things being equal, a one per cent increase in log in oil rent is associated with a significant decrease in the log in change of real GDP per capita of over 0.05 per cent on average. The size of the coefficient is about 40\% and 20\% higher than subsample period 1995-2017 (column 2 in Table 2) and the full sample period 1980-2017 (column 3 in Table 2) respectively.

From column 2 in Table 2, we observe that the coefficient of interaction term (between $\log$ in oil rent and log in trade openness) is positive and statistically significant during the period 1995-2017. This result indicates that trade openness has a significant impact on reducing the resource curse during that period. However, we do not find any statistically significant impact of trade openness during the period 1980-1994 (refer to column 1), although the coefficient is positive and similar with the other periods. Therefore, we can say that the result in the period 1995-2017 led to the results for the full sample period (column 3).

\footnotetext{
${ }^{17}$ We split sample periods based on the introduction of the WTO, not the GATT, because most economies started following the WTO's rules and regulations in 1995 (124 countries in 1995 and 164 in 2017), prior to the GATT in 1947.
} 
Table 2: Change in real GDP per capita and oil rent (\% of GDP) in different sample periods.

\begin{tabular}{|c|c|c|c|}
\hline & \multicolumn{3}{|c|}{ Dependent variable: $\Delta L G D P_{i, t}$} \\
\hline & $\begin{array}{c}1980-1994 \\
\text { (1) }\end{array}$ & $\begin{array}{c}1995-2017 \\
\text { (2) }\end{array}$ & $\begin{array}{c}1980-2017 \\
\text { (3) }\end{array}$ \\
\hline \multirow{3}{*}{$\Delta L G D P_{i, t-1}$} & $0.32 * * *$ & $0.36 * * *$ & $0.40 * * *$ \\
\hline & $(0.04)$ & $(0.02)$ & $(0.02)$ \\
\hline & {$[0.05]$} & [0.03] & [0.03] \\
\hline \multirow[t]{3}{*}{$L O I L_{i, t}$} & $-0.05^{*}$ & $-0.03 *$ & $-0.04 * * *$ \\
\hline & $(0.03)$ & $(0.01)$ & $(0.01)$ \\
\hline & {$[0.03]$} & {$[0.02]$} & {$[0.01]$} \\
\hline \multirow[t]{3}{*}{$L U N_{i, t}$} & -0.004 & -0.002 & -0.0007 \\
\hline & $(0.004)$ & $(0.002)$ & $(0.001)$ \\
\hline & [0.005] & [0.003] & {$[0.003]$} \\
\hline \multirow{3}{*}{$L F D I_{i, t}$} & 0.25 & -0.001 & -0.002 \\
\hline & $(0.24)$ & $(0.005)$ & $(0.005)$ \\
\hline & [0.23] & [0.004] & {$[0.004]$} \\
\hline \multirow[t]{3}{*}{$L C A B_{i, t}$} & $-0.28 * *$ & $-0.07 * *$ & $-0.08 * *$ \\
\hline & $(0.11)$ & $(0.03)$ & $(0.03)$ \\
\hline & {$[0.22]$} & {$[0.04]$} & {$[0.04]$} \\
\hline \multirow{3}{*}{$L M I_{i, t}$} & $-0.04 * * *$ & $-0.01 * * *$ & $-0.01 * * *$ \\
\hline & $(0.01)$ & $(0.004)$ & $(0.003)$ \\
\hline & [0.02] & [0.005] & {$[0.004]$} \\
\hline \multirow[t]{3}{*}{$L M O R_{i, t}$} & -0.0009 & $0.01 * * *$ & $0.01 * * *$ \\
\hline & $(0.02)$ & $(0.005)$ & $(0.004)$ \\
\hline & [0.02] & {$[0.005]$} & [0.004] \\
\hline \multirow{3}{*}{$L T_{i, t}$} & $0.02 *$ & $0.01 * * *$ & $0.009 * *$ \\
\hline & $(0.01)$ & $(0.004)$ & $(0.003)$ \\
\hline & {$[0.01]$} & [0.006] & [0.004] \\
\hline \multirow{3}{*}{$L T_{i, t} * L O I L_{i, t}$} & 0.01 & $0.01 * * *$ & $0.01 * * *$ \\
\hline & $(0.008)$ & $(0.004)$ & $(0.002)$ \\
\hline & [0.008] & [0.005] & [0.003] \\
\hline $\mathrm{R}^{2}$ & 0.49 & 0.50 & 0.48 \\
\hline Adjusted $\mathrm{R}^{2}$ & 0.41 & 0.47 & 0.44 \\
\hline Periods & 38 & 23 & 38 \\
\hline Countries & 57 & 95 & 95 \\
\hline Observations & 564 & 1,935 & 2,499 \\
\hline
\end{tabular}

Note: Standard errors are presented below the corresponding coefficients in the bracket. ***, ** and * indicate the significance at the $10 \%, 5 \%$, and $1 \%$ level respectively. Cluster standard errors are presented in square brackets.

From the above discussion, it is concluded that there is a negative relationship between log in oil rent (\% of GDP) and log in change of real GDP per capita; that is, the resource curse. Although in classical theories it is assumed that an abundance of natural resources is a blessing for economic growth, we concur with Sachs and Warner (1995) who empirically show that 
resources are a curse for the economy. However, we provide evidence that trade openness can reduce the resource curse.

\subsection{Robustness results}

To check the robustness of the results, we use two alternative measures of trade opennessexports (\% of GDP) and imports (\% of GDP). ${ }^{18}$ Our empirical findings show that the resource curse reduces with the increase of both exports and imports. With the increase of exports, economies can gain access to international prices and earn more revenue from royalties, thereby increasing real GDP per capita. On the other hand, countries can import advance technologies to more efficiently extract oil resources and/or produce final products to earn more revenue that increases real GDP per capita. For further robustness, we use natural resource rent (\% of GDP) instead of oil rent (\% of GDP) as a measure of resource abundance and find similar results. ${ }^{19}$ All robustness findings are presented in Tables A6-A10 in Appendix 3.

\subsection{Discussion of the results}

Overall, the panel data regression models suggest that having an abundance of oil resources plays a significant role in slowing economic growth—that is, it serves as a resource curse. Many reasons have been put forward in the literature for this surprising result, including rentseeking behaviour, poor institutional quality, commodity price volatility and lack of diversification. In this study, we investigated the impact of trade openness in reducing the resource curse. Our empirical findings show that trade openness significantly decreases the resource curse in our full sample period (1980-2017). More open trade policies provide access to advanced technologies that increase efficiency by reallocating the factors of production.

\footnotetext{
${ }^{18}$ Exports (\% of GDP) and Imports (\% of GDP) represent the value of all goods and services provided and received to and from the rest of the world respectively.

${ }^{19}$ Natural resource rent (\% of GDP) is the sum of oil rents, natural gas rents, coal rents, mineral rents and forest rents. Data for Exports (\% of GDP), Imports (\% of GDP) and natural resource rent (\% of GDP) are collected from the World Development Indicators of the WB.
} 
These trade policies also facilitate access to large markets where increasing competition drives innovations and strengthens managerial skills which in turn generates substantial economic growth. Accordingly, Arezki and Van der Ploeg (2011) report that the resource curse has turned into a blessing in countries with a high degree of trade openness such as Australia, Bolivia, Barbados, Canada, Chile, Malaysia and the United States.

To understand the role of the WTO in increasing merchandise trade, we split our sample period into two subsample periods, 1980-1994 (pre-WTO) and 1995-2017 (post-WTO). Our empirical findings suggest that trade openness had a significant impact on reducing the resource curse in the sample period 1995-2017. However, there was no significant effect in the sample period 1980-1994, possibly due to the fact that total merchandise trade increased after the commencement of the WTO in 1995 which helped to weaken the strength of the dynamics driving the resource curse.

Overall, based on our empirical findings, we can argue that outward-looking trade policy is helpful for economic growth and reduces the risk of experiencing the resource curse. Therefore, policymakers should concentrate on how they can make the economy more open by reducing existing tariffs and non-tariff barriers. Increased international trade (both export and import) helps economies to be more efficient by enabling the adoption of new technologies and sharing of advanced knowledge which generates long-run economic growth.

\subsection{Marginal effect}

Marginal effect tells us how the dependent variable changes when a specific explanatory variable change in the regression analysis. In case of continuous variables, marginal effect measures the instantaneous rate of change. Marginal effect estimation provides a good estimate to the amount of change in the dependent variable that will be produced by a change in 
independent variables. In this study, we compute the marginal effect of oil rent on the change in GDP per capita. Based on the estimates in Table 1, this produced:

$$
\frac{d\left(\Delta L G D P_{i, t}\right)}{d(L O I L i, t)}=-0.04+0.01(\text { trade openness })
$$

From the above equation, we can see that the marginal effect of oil rent on the change in real GDP per capita is an increasing function of trade openness. Figure 4a plots the marginal effect, $\frac{d(\triangle L G D P)}{d(L O I L)}$, on the $\mathrm{Y}$-axis and trade openness on the $\mathrm{X}$-axis. From this plot, we can observe that the marginal effect of the oil rent on economic growth is an increasing function of trade openness in the full sample period. We also observe from Figure 4a that this effect becomes positive and significant with higher trade openness. In Figures $4 \mathrm{~b}$ and $4 \mathrm{c}$, we present the marginal effect of trade openness on GDP for the sample period 1980-1994 and 1995-2017 respectively, and we observe that in the sample period 1980-1994 there is no significant impact of trade openness on GDP. So, the results in the sample period 1995-2017 led to the results for the full sample period. ${ }^{20}$

Figure 4a: Marginal effect of oil rent on economic growth (full sample period 1980-2017)

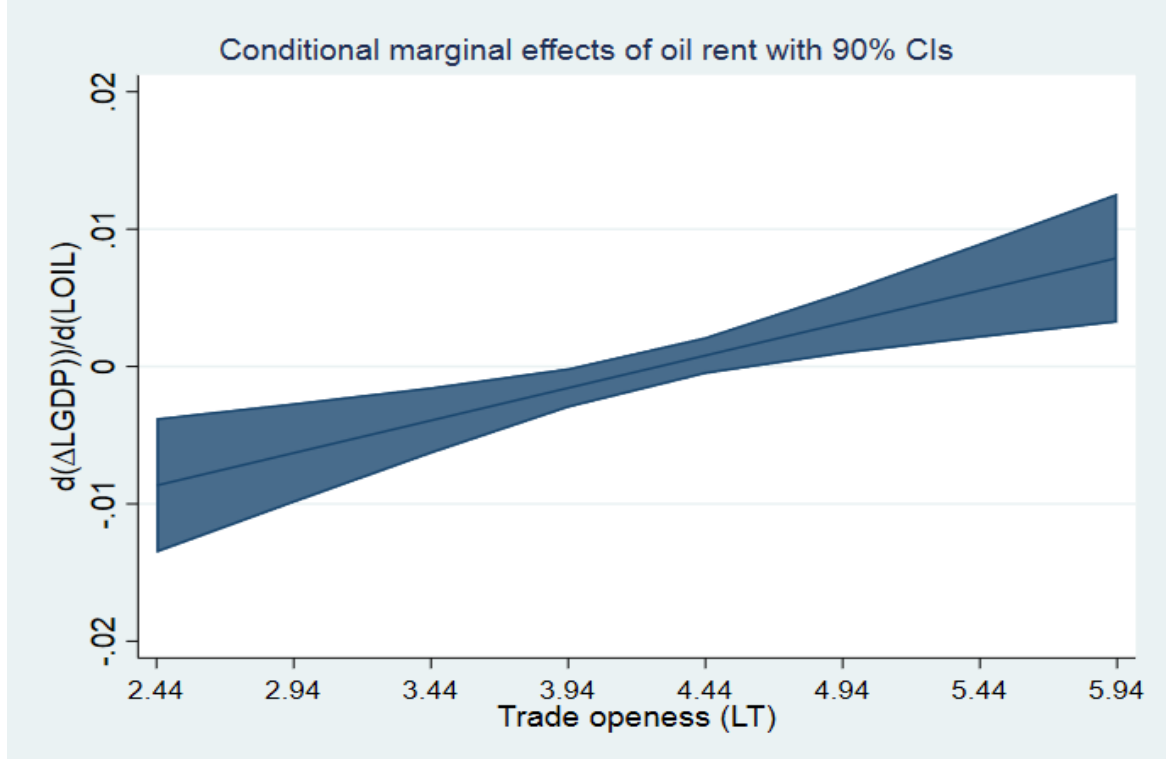

${ }^{20}$ The figures of all robust analysis are presented in Appendix 4 (Figures A1, A2, A3, A4, and A5). 
Figure 4b: Marginal effect of oil rent on economic growth (sample period 1980-1994)

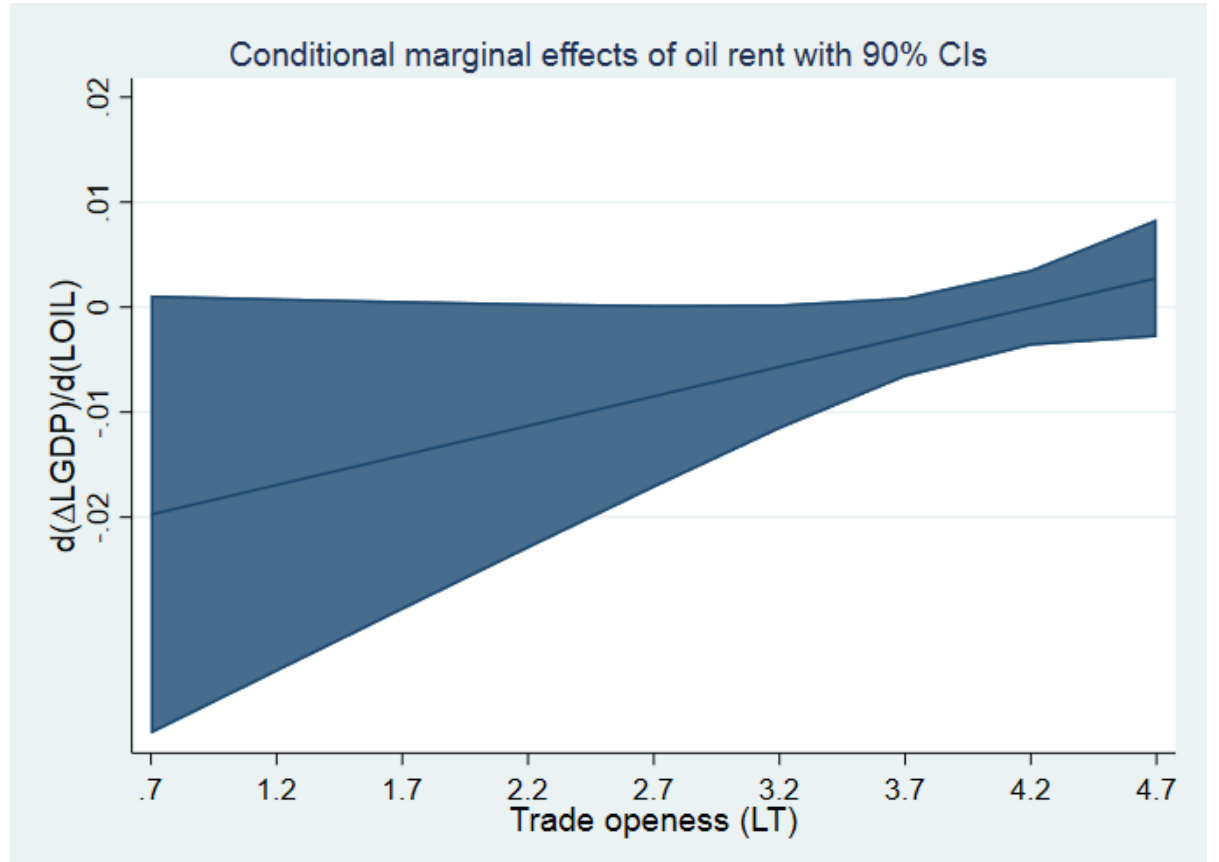

Figure 4c: Marginal effect of oil rent on economic growth (sample period 1995-2017)

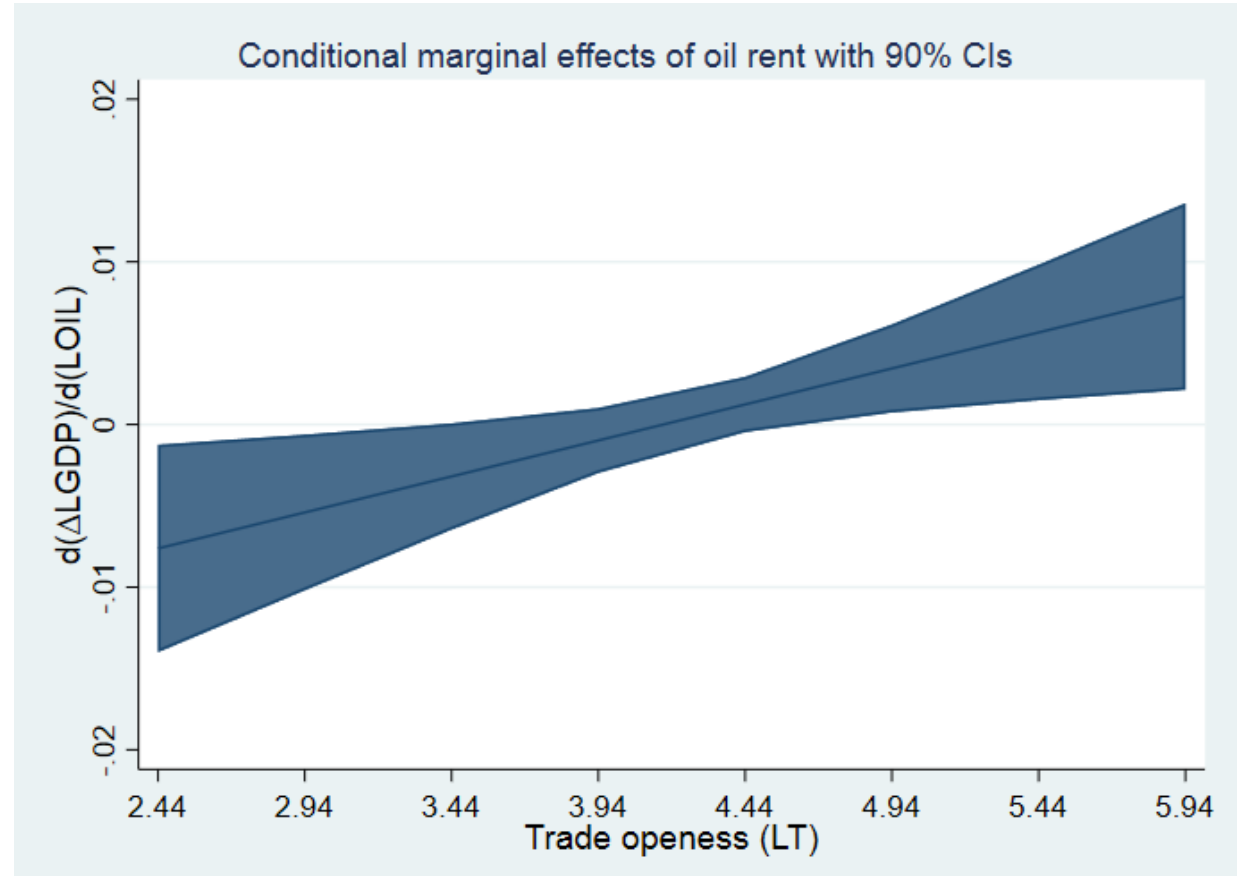




\section{Conclusion}

This study aims to revisit the resource curse paradox and examines the role of trade openness in reducing the resource curse. Using different dynamic panel data models for 95 countries for the period 1980-2017, this study finds that economic growth decreases with the increase of oil resource abundance. A one per cent increase in oil rent causes a 0.04 per cent decrease in real GDP per capita. Although our empirical findings support the resource curse hypothesis, the study finds that trade openness is a possible channel to reduce the resource curse. On average, trade openness reduces the negative effect of oil rent on real GDP per capita by $25 \%$. Trade openness allows countries to obtain competitive prices for their resources in the international market and access advanced technologies to more efficiently extract resources. We also find that trade openness significantly affects the resource curse after the introduction of the WTO. An important policy implication is that natural resource-rich economies that want to reduce the resource curse should consider further opening their economies.

This study can be extended by focusing on another transmission channel of the resource curse, income inequality. According to Fum and Hodler (2010) and Parcero and Papyrakis (2016), income inequality is high in resource-rich countries, especially those with point-source resources. One reason is that inefficient allocation of resources among sectors increases income inequality. Trade openness plays an important role in reallocating resources in the sectors where a country has a comparative advantage. This efficient distribution of resources helps to reduce income inequality in resource-rich countries and, thus, spurs economic growth. 


\section{References}

Andersen, TB, Barslund, M, Hansen, CW, Harr, T \& Jensen, PS 2014, 'How much did China's WTO accession increase economic growth in resource-rich countries?', China Economic Review, vol. 30, pp. 16-26.

Arezki, R \& Brückner, M 2011, 'Oil rents, corruption, and state stability: evidence from panel data regressions’, European Economic Review, vol. 55, pp. 955-963.

Arezki, R \& Van der Ploeg, F 2011, 'Do natural resources depress income per capita?' Review of Development Economics, vol. 15, pp. 504-521.

Asteriou, D \& Hall, SG 2015, Applied econometrics, Palgrave Macmillan.

Auty, R 1993, Sustaining development in mineral economies: the resource curse thesis, Routledge, London, UK.

Badeeb, RA, Lean, HH \& Clark, J 2017, 'The evolution of the natural resource curse thesis: a critical literature survey’, Resources Policy, vol. 51, pp. 123-134.

Başkaya, YS, Hülagü, T \& Küçük, H 2013, 'Oil price uncertainty in a small open economy’, IMF Economic Review, vol. 61, pp. 168-198.

Bellemare, MF, Barrett, CB \& Just, DR 2013, 'The welfare impacts of commodity price volatility: evidence from rural Ethiopia’, American Journal of Agricultural Economics, vol. 95, pp. 877-899.

Bhattacharyya, S \& Hodler, R 2010, 'Natural resources, democracy and corruption', European Economic Review, vol. 54, pp. 608-621.

Bjorvatn, K, Farzanegan, MR \& Schneider, F 2012, 'Resource curse and power balance: evidence from oil-rich countries’, World Development, vol. 40, pp. 1308-1316.

Borensztein, E, De Gregorio, J \& Lee, J 1998, 'How does foreign direct investment affect economic growth?’, Journal of International Economics, vol. 45, pp. 115-135.

Boschini, AD, Pettersson, J \& Roine, J 2007, 'Resource curse or not: a question of appropriability’, Scandinavian Journal of Economics, vol. 109, pp. 593-617.

BP 2017, BP statistical review of world energy June 2017, viewed X, $<$ http://www.bp.com/en/global/corporate/energy-economics/statistical-review-of-worldenergy.html>.

Braun, M \& Raddatz, C 2008, 'The politics of financial development: evidence from trade liberalization’, The Journal of Finance, vol. 63, pp. 1469-1508.

Bredin, D \& Fountas, S 2005, 'Macroeconomic uncertainty and macroeconomic performance: are they related?’, The Manchester School, vol. 73, pp. 58-76.

Cappelen, Å, Gleditsch, NP \& Bjerkholt, O 1984, 'Military spending and economic growth in the OECD countries', Journal of Peace Research, vol. 21, pp. 361-373. 
Catão, L \& Kapur, S 2004, Missing link: volatility and the debt intolerance paradox, International Monetary Fund.

Cho, SW \& Diaz, JP 2011, 'The welfare impact of trade liberalization', Economic Inquiry, vol. 49, pp. 379-397.

Coates, B \& Luu, N 2012, 'China's emergence in global commodity markets', Economic Round-up, vol. 1, pp. 1-30.

Collier, P \& Hoeffler, A 2005, 'Resource rents, governance, and conflict', Journal of Conflict Resolution, vol. 49, pp. 625-633.

Corden, WM 1984, 'Booming sector and Dutch disease economics: survey and consolidation', Oxford Economic Papers, vol. 36, pp. 359-380.

Corden, WM \& Neary, JP 1982, 'Booming sector and de-industrialisation in a small open economy’, The Economic Journal, vol. 92, pp. 825-848.

De Ferranti, D, Perry, GE, Lederman, D \& Maloney, WE 2002, From natural resources to the knowledge economy: trade and job quality, World Bank.

De Soysa, I \& Neumayer, E 2007, 'Resource wealth and the risk of civil war onset: results from a new dataset of natural resource rents, 1970-1999', Conflict Management and Peace Science, vol. 24, pp. 201-218.

Deacon, RT \& Rode, A 2015, 'Rent seeking and the resource curse' in RD Congleton and AL Hillman (eds), Companion to the political economy of rent seeking, Edward Elgar, pp. X-X.

Dehn, J 2000, Commodity price uncertainty in developing countries, World Bank.

Dutt, P 2009, 'Trade protection and bureaucratic corruption: an empirical investigation', Canadian Journal of Economics/Revue canadienne d'économique, vol. 42, pp. 155-183.

Dwyer, A, Gardner, G \& Williams, T 2011, 'Global commodity markets-price volatility and financialisation', RBA Bulletin, June, pp. 49-57.

Fum, RM \& Hodler, R 2010, 'Natural resources and income inequality: the role of ethnic divisions’, Economics Letters, vol. 107, pp. 360-363.

Goderis, B 2008, Commodity prices, growth, and the natural resource curse: reconciling a conundrum.

Goldstein, JL, Rivers, D \& Tomz, M 2007, 'Institutions in international relations: understanding the effects of the GATT and the WTO on world trade', International Organization, vol. 61, pp. 37-67.

Guo, H \& Kliesen, KL 2005, 'Oil price volatility and US macroeconomic activity', ReviewFederal Reserve Bank of Saint Louis, vol. 87, pp. 669-683.

Gylfason, T 2000, Resources, agriculture and economic growth in economies in transition. 
2001, 'Natural resources, education, and economic development', European Economic Review, vol. 45, pp. 847-859.

Henriques, I \& Sadorsky, P 2011, 'The effect of oil price volatility on strategic investment', Energy Economics, vol. 33, pp. 79-87.

Hodler, R 2006, 'The curse of natural resources in fractionalized countries', European Economic Review, vol. 50, pp. 1367-1386.

Hsiao, C 2014, Analysis of panel data, Cambridge University Press.

Iimi, A 2007, 'Escaping from the resource curse: evidence from Botswana and the rest of the world', IMF Staff Papers, vol. 54, pp. 663-699.

Isham, J, Woolcock, M, Pritchett, L \& Busby, G 2005, 'The varieties of resource experience: natural resource export structures and the political economy of economic growth', The World Bank Economic Review, vol. 19, pp. 141-174.

Kalemli-Ozcan, S 2002, 'Does the mortality decline promote economic growth?', Journal of Economic Growth, vol. 7, pp. 411-439.

Lam, R \& Wantchekon, L 2003, Political Dutch disease, manuscript, Department of Politics, New York University.

Masih, R, Peters, S \& De Mello, L 2011, 'Oil price volatility and stock price fluctuations in an emerging market: evidence from South Korea’, Energy Economics, vol. 33, pp. 975-986.

Masten, SE \& Crocker, KJ 1985, 'Efficient adaptation in long-term contracts: take-or-pay provisions for natural gas’, The American Economic Review, vol. 75, pp. 1083-1093.

Mavrotas, G, Murshed, SM \& Torres, S 2011, 'Natural resource dependence and economic performance in the 1970-2000 period', Review of Development Economics, vol. 15, pp. 124138.

Mehlum, H, Moene, K \& Torvik, R 2006, 'Institutions and the resource curse', The Economic Journal, vol. 116, pp. 1-20.

Nicita, A, Olarreaga, M \& Silva, PA 2013, Cooperation in WTO’s tariff waters.

Papyrakis, E \& Gerlagh, R 2007, 'Resource abundance and economic growth in the United States’, European Economic Review, vol. 51, pp. 1011-1039.

Parcero, OJ \& Papyrakis, E 2016, 'Income inequality and the oil resource curse', Resource and Energy Economics, vol. 45, pp. 159-177.

Pedersen, PO 2000, The changing structure of transport under trade liberalisation and globalization and its impact on African development, CDR working paper.

Sachs, JD \& Warner, AM 1995, Natural resource abundance and economic growth, National Bureau of Economic Research. 
Sahin, IE \& Mucuk, M 2014, 'The effect of current account deficit on economic growth: the case of Turkey', Proceedings of International Academic Conferences, International Institute of Social and Economic Sciences.

Sala-i-Martin, X \& Subramanian, A 2013, 'Addressing the natural resource curse: an illustration from Nigeria’, Journal of African Economies, vol. 22, pp. 570-615.

Salim, R \& Rafiq, S 2011, 'The impact of crude oil price volatility on selected Asian emerging economies', Proceedings of Global Business and Social Science Research Conference, World Business Institute Australia, pp. 1-33.

Sarmidi, T, Hook Law, S \& Jafari, Y 2014, 'Resource curse: new evidence on the role of institutions’, International Economic Journal, vol. 28, pp. 191-206.

Subramanian, A \& Wei, S-J 2007, 'The WTO promotes trade, strongly but unevenly', Journal of International Economics, vol. 72, pp. 151-175.

Tomz, M, Goldstein, JL \& Rivers, D 2007, 'Do we really know that the WTO increases trade? Comment’, American Economic Review, vol. 97, pp. 2005-2018.

Torivk, R 2009, 'Why do some resource-abundant countries succeed while others do not?', Oxford Review of Economic Policy, vol. 25, pp. 241-256.

Tujula, M \& Wolswijk, G 2004, What determines fiscal balances? An empirical investigation in determinants of changes in OECD budget balances.

United Nations Conference on Trade and Development 2016, UNCTAD handbook of statistics 2016, viewed September 2019, <https://unctad.org/en/pages/PublicationWebflyer.aspx?publicationid=1667>.

Van der Ploeg, F 2011, 'Natural resources: curse or blessing?', Journal of Economic Literature, vol. 49, pp. 366-420.

World Bank 2019, World Development Indicators, viewed September 2019, < https://data.worldbank.org/indicator/NY.GDP.MKTP.KD>. 


\section{Appendix 1}

Table A1: Description of the variables

\begin{tabular}{|c|c|c|c|}
\hline Variables & Mnemonic & Description & Source \\
\hline \multicolumn{4}{|l|}{ Dependent variable } \\
\hline Real GDP per capita & $L G D P_{i, t}$ & $\begin{array}{l}\text { GDP per capita is gross domestic } \\
\text { product divided by mid-year } \\
\text { population. Data are in constant } 2010 \\
\text { US dollars. }\end{array}$ & WDI, WB \\
\hline \multicolumn{4}{|l|}{ Control variables } \\
\hline Oil rents (\% of GDP) & $L^{\prime O I L} L_{i, t}$ & $\begin{array}{l}\text { Oil rents are the difference between the } \\
\text { value of crude oil production at } \\
\text { regional prices and total costs of } \\
\text { production. We add } 1 \text { before } \\
\text { converting into logarithmic form. }\end{array}$ & WDI, WB \\
\hline $\begin{array}{l}\text { Unemployment rate (\% } \\
\text { of total labour force) }\end{array}$ & $L U N_{i, t}$ & $\begin{array}{l}\text { Unemployment rate can be defined by } \\
\text { the OECD harmonised definition. The } \\
\text { OECD harmonised unemployment rate } \\
\text { gives the number of unemployed } \\
\text { persons as a percentage of the labour } \\
\text { force. }\end{array}$ & $\begin{array}{l}\text { World } \\
\text { Economic } \\
\text { Outlook, IMF }\end{array}$ \\
\hline $\begin{array}{l}\text { Foreign direct } \\
\text { investment, net } \\
\text { outflows (\% of GDP) }\end{array}$ & $L F D I_{i, t}$ & $\begin{array}{l}\text { Foreign direct investment refers to } \\
\text { direct investment equity flows in an } \\
\text { economy. It is the sum of equity } \\
\text { capital, reinvestment of earnings, and } \\
\text { other capital. We add } 100 \text { before } \\
\text { converting into logarithmic form. }\end{array}$ & WDI, WB \\
\hline $\begin{array}{l}\text { Current account balance } \\
\text { (\% of GDP) }\end{array}$ & $L C A B_{i, t}$ & $\begin{array}{l}\text { Current account balance is the sum of } \\
\text { net exports of goods and services, net } \\
\text { primary income and net secondary } \\
\text { income. }\end{array}$ & WDI, WB \\
\hline $\begin{array}{l}\text { Military expense (\% of } \\
\text { GDP) }\end{array}$ & $L M I_{i, t}$ & $\begin{array}{l}\text { Military expenditures data from SIPRI } \\
\text { are derived from the NATO definition, } \\
\text { which includes all current and capital } \\
\text { expenditures on the armed forces. We } \\
\text { add } 10 \text { to convert logarithmic form. }\end{array}$ & WDI, WB \\
\hline $\begin{array}{l}\text { Mortality rate, infant } \\
\text { (per } 1,000 \text { live births) }\end{array}$ & $L M O R_{i, t}$ & $\begin{array}{l}\text { Infant mortality rate is the number of } \\
\text { infants dying before reaching one year } \\
\text { of age, per } 1,000 \text { live births in a given } \\
\text { year. }\end{array}$ & WDI, WB \\
\hline $\begin{array}{l}\text { Trade openness (\% of } \\
\text { GDP) }\end{array}$ & $L T_{i, t}$ & $\begin{array}{l}\text { Trade is the sum of exports and imports } \\
\text { of goods and services measured as a } \\
\text { share of GDP. }\end{array}$ & WDI, WB \\
\hline
\end{tabular}

Note: WDI = World Development Indicators. We use first difference to get the data in stationary in real GDP per capita series and expressed as $\Delta L G D P_{i, t}$. 
Change in GDP per capita $\left(\Delta \boldsymbol{L} G \boldsymbol{D P} \boldsymbol{P}_{i, t}\right)$ : Change in log of real GDP per capita is our dependent variable and is denoted by $\triangle L G D P_{i, t}$ in the model. As we want to measure the impact of oil rent (\% of GDP) on the economic growth, we use change in log of real GDP per capita because it represents the level of development of a country.

Oil rent $\left(\boldsymbol{L O I} \boldsymbol{L}_{i, t}\right)$ : According to the conventional view, resource abundance stimulates economic growth. However, Sachs and Warner (1995) argue that resource abundance impede economic growth which is known as resource curse. By following Bjorvatn, Farzanegan and Schneider (2012), Arezki and Brückner (2011), Bhattacharyya and Hodler (2010) and Collier and Hoeffler (2005), we use oil rents (\% of GDP) as a measure of natural resource abundance. Rents are basically net profits from resource extraction, defined as the value of the product minus the total cost of production. Rents measure the value of natural resources for a country more precisely, providing a less ambiguous measure of resource abundance compared with those used previously such as primary commodity exports, oil exports and reserves. In this study, we expect the sign of oil rent (\% of GDP) will be negative.

Unemployment rate $\left(\boldsymbol{L U} \boldsymbol{N}_{i, t}\right)$ : According to the Okun's law, a one per cent increase in unemployment rate causes two per cent decreases in GDP. A country faces higher costs in the form of unemployment benefits which negatively affects economic growth. An increased unemployment rate also increases the chance of social unrest.

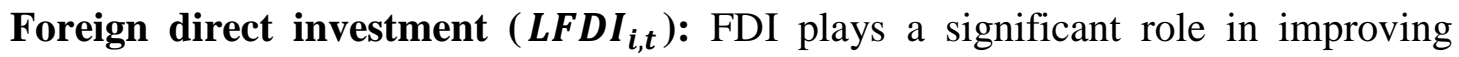
economic growth. It also indicates the strength of a country's financial market. According to Borensztein, De Gregorio and Lee (1998), FDI is an important vehicle for the transfer of technologies, knowledge and human capital, all associated with higher productivity. Thus, the relationship between FDI and change in real GDP per capita would be positive. 
Current account balance $\left(\boldsymbol{L C} \boldsymbol{A} \boldsymbol{B}_{\boldsymbol{i}, t}\right)$ : It is expected that current account balance has a positive impact on economic growth. If a country's balance increases, indicating that its exports exceed its imports, that encourages investment and FDI. Sahin and Mucuk (2014) found that current account deficit negatively affects economic growth in developing countries.

Military expense $\left(\boldsymbol{L} \boldsymbol{M}_{\boldsymbol{i}, \boldsymbol{t}}\right)$ : According to Cappelen, Gleditsch and Bjerkholt (1984), military expenditure reduces economic growth. As this expenditure increases, so does government total expenditure, leading to higher tax rates in the private sector that ultimately reduce private investment and the country's output.

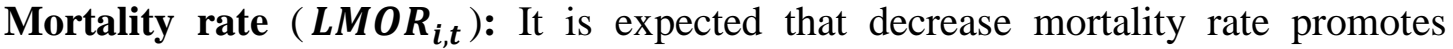
economic growth. According to the Kalemli-Ozcan (2002) decrease in mortality rate reduces the precautionary demand for children and increases potential investment in each child that increase the human capital and productivity for an economy.

Trade openness $\left(\boldsymbol{L} \boldsymbol{T}_{i, t}\right)$ : Trade openness (\% of GDP) is calculated as the total of exports and imports expressed as a percentage share of GDP. According to endogenous growth theories, a country with more trade openness will grow faster than a country with a lower degree of openness, because the former has more opportunity to adopt new technologies. Also, trade openness increases the flow of international capital in the form of FDI. There is likely to be less interest in investing in an economy that imposes tariffs and non-tariff barriers on investment and that creates barriers to the repatriation of capital and profits. Consequently, trade openness boosts international trade and capital flows which stimulate economic growth. It is expected that the sign of trade openness (\% of GDP) will be positive.

Interaction term: In this study, we are interested in the interaction between trade openness (\% of GDP) and oil rent (\% of GDP) to examine the hypothesis that the resource curse will decrease as the degree of trade openness increases. This is because trade openness 
increases opportunities to obtain a higher price for resources in the international market and use advanced technologies to improve productivity and economic growth. We expect a positive sign for this coefficient.

Table A2: List of countries $(n=95)$

\begin{tabular}{lllll}
\hline Albania & China & Indonesia & Mexico & Serbia \\
Algeria & Colombia & Iran & Moldova & Seychelles \\
Argentina & Costa Rica & Irelands & Mongolia & Singapore \\
Armenia & Croatia & Israel & Morocco & Slovak Rep. \\
Australia & Cyprus & Italy & Netherlands & Slovenia \\
Austria & Czech Rep. & Jamaica & New Zealand & South Africa \\
Azerbaijan & Denmark & Japan & Nicaragua & Spain \\
Bahrain & Dominican Rep. & Jordan & Nigeria & Sri Lanka \\
Belarus & Ecuador & Kazakhstan & Norway & Sweden \\
Belgium & Egypt, Arab Rep. & Korea, Rep. & Pakistan & Switzerland \\
Belize & El Salvador & Kuwait & Panama & Thailand \\
Bolivia & Estonia & Kyrgyz Rep. & Paraguay & Tunisia \\
Bosnia \& Herzegovina & Finland & Latvia & Peru & Turkey \\
Brazil & France & Lithuania & Philippines & Ukraine \\
Brunei Darussalam & Georgia & Luxemburg & Poland & The UK \\
Bulgaria & Germany & Macedonia & Portugal & The USA \\
Cabo Verde & Greece & Malaysia & Romania & Uruguay \\
Canada & Honduras & Malta & Russian Federation & Venezuela \\
Chile & Hungary & Mauritius & Saudi Arabia & Vietnam \\
\hline
\end{tabular}

Table A3: Unit root test

\begin{tabular}{|c|c|c|c|c|c|c|c|c|}
\hline & \multicolumn{4}{|c|}{ Augmented Ducky-Fuller (ADF) } & \multicolumn{4}{|c|}{ Phillips-Peron (PP) } \\
\hline & \multicolumn{2}{|c|}{ At level } & \multicolumn{2}{|c|}{$1^{\text {st }}$ difference } & \multicolumn{2}{|l|}{ At level } & \multicolumn{2}{|c|}{$1^{\text {st }}$ difference } \\
\hline & statistics & $p$-value & statistics & $p$-value & statistics & $p$-value & statistics & $p$-value \\
\hline LGDP & 138.67 & 0.99 & $1,062.80$ & 0.00 & 151.79 & 0.98 & $1,156.21$ & 0.00 \\
\hline LOIL & 315.05 & 0.00 & - & - & 301.44 & 0.00 & - & - \\
\hline LUN & 362.38 & 0.00 & - & - & 364.88 & 0.00 & - & - \\
\hline LFDI & 509.65 & 0.00 & - & - & 923.37 & 0.00 & - & - \\
\hline LCAB & 429.20 & 0.00 & - & - & 459.19 & 0.00 & - & - \\
\hline LMI & 235.43 & 0.00 & - & - & 278.75 & 0.00 & - & - \\
\hline LMOR & 229.90 & 0.02 & & -- & 390.70 & 0.00 & - & - \\
\hline $\mathrm{LT}$ & 276.40 & 0.00 & - & - & 298.34 & 0.00 & - & - \\
\hline
\end{tabular}

Note: LGDP $=\log$ of real GDP per capita, LOIL $=$ Log of oil rent, LUN $=$ Log of unemployment rate, LFDI $=$ Log of foreign direct investment, $\mathrm{LCAB}=\mathrm{Log}$ of current account balance, LMI = Log of military expense, $\mathrm{LMOR}=\mathrm{Log}$ of mortality rate, $\mathrm{LT}=\mathrm{Log}$ of trade openness. 
Table A4: Descriptive statistics

\begin{tabular}{lcccccccc}
\cline { 2 - 8 } & DLGDP & LOIL & LUN & LFDI & LCAB & LMI & LMOR & LT \\
\cline { 2 - 8 } Mean & 0.02 & 0.56 & 1.98 & 4.62 & 5.51 & 1.06 & 2.41 & 4.29 \\
Median & 0.02 & 0.04 & 2.01 & 4.61 & 5.51 & 1.02 & 2.39 & 4.28 \\
Maximum & 0.28 & 4.13 & 3.61 & 5.76 & 5.68 & 3.05 & 4.76 & 6.08 \\
Minimum & -0.18 & 0.000 & -3.68 & 2.33 & 5.32 & 0.00 & 0.53 & 2.44 \\
Std. Dev. & 0.03 & 0.90 & 0.64 & 0.11 & 0.02 & 0.46 & 0.87 & 0.56 \\
Skewness & -0.35 & 1.83 & -0.80 & -5.42 & 0.62 & 0.54 & 0.17 & 0.11 \\
Kurtosis & 7.28 & 5.66 & 6.50 & 162.17 & 9.06 & 4.11 & 2.29 & 3.54 \\
Observations & 2506 & 2506 & 2506 & 2506 & 2506 & 2506 & 2506 & 2506 \\
\hline
\end{tabular}

Note: $\triangle$ LGDP = Change in log of real GDP per capita, LOIL = Log of oil rent, LUN = Log of unemployment rate, LFDI $=$ Log of foreign direct investment, LCAB = Log of current account balance, LMI = Log of military expense, LMOR $=$ Log of mortality rate, $\mathrm{LT}=\mathrm{Log}$ of trade openness.

Table A5: Correlation matrix

\begin{tabular}{lcccccccc}
\cline { 2 - 8 } & $\Delta$ LGDP & LOIL & LUN & LFDI & LCAB & LMI & LMOR & LT \\
\cline { 2 - 8 }$\Delta$ LGDP & 1.00 & & & & & & & \\
LOIL & -0.02 & 1.00 & & & & & & \\
LUN & -0.03 & -0.14 & 1.00 & & & & & \\
LFDI & 0.008 & -0.01 & -0.04 & 1.00 & & & & \\
LCAB & -0.09 & 0.36 & -0.26 & 0.07 & 1.00 & & & \\
LMI & -0.06 & 0.18 & -0.02 & -0.02 & 0.15 & 1.00 & & \\
LMOR & 0.04 & 0.28 & 0.17 & -0.14 & -0.20 & 0.09 & 1.00 & \\
LT & 0.13 & -0.16 & -0.17 & 0.09 & 0.06 & -0.19 & -0.32 & 1.00 \\
\hline
\end{tabular}

Note: $\triangle$ LGDP = Change in log of real GDP per capita, LOIL = Log of oil rent, LUN = Log of unemployment rate, LFDI $=$ Log of foreign direct investment, $\mathrm{LCAB}=\mathrm{Log}$ of current account balance, $\mathrm{LMI}=$ Log of military expense, $\mathrm{LMOR}=\mathrm{Log}$ of mortality rate, $\mathrm{LT}=\mathrm{Log}$ of trade openness. 


\section{Appendix 2}

\section{A2.1. PLS model}

In the PLS model, we have pooled all the observations in ordinary least square regression, meaning that implicitly we assume the coefficient is the same for all the individuals. This model does not hold any unobservable heterogeneity among the variables. We can write equation (1) in following way:

$$
\begin{aligned}
& \Delta L G D P_{i, t}=\beta_{0}+\beta_{1} \Delta L G D P_{i, t-1}+\beta_{2} L O I L_{i, t}+\beta_{3} L U N_{i, t}+\beta_{4} L F D I_{i, t}+\beta_{5} L C A B_{i, t}+ \\
& \beta_{6} L M I_{i, t}+L M O R_{i, t}+\beta_{8} L T_{i, t}+\beta_{9} L T_{i, t} * L O I L_{i, t}+\varepsilon_{i, t}
\end{aligned}
$$

\section{A2.2. Cross-section fixed effect model}

We use the fixed effect model to further investigate the effect of oil rent on economic growth. The cross-section fixed effect model essentially captures all effects that are specific to an individual country and do not vary over time. For example, GDP per capita, trade and oil rent will vary between countries due to their differing geographies, natural endowments, political and cultural systems and other basic factors that vary between countries, but not over time. Fixed effect model assumes that these factors may have an impact on the predictor or outcome variable, and we need to control for this. Cross-section fixed effect model removes the effect of those time-invariant characteristics so that we can assess the net impact of oil rent on economic growth. We can write equation (1) with fixed effect as follows:

$$
\begin{aligned}
& \triangle L G D P_{i, t}=\beta_{0 i}+\beta_{1} \Delta L G D P_{i, t-1}+\beta_{2} L O I L_{i, t}+\beta_{3} L U N_{i, t}+\beta_{4} L F D I_{i, t}+L C A B_{i, t}+ \\
& \beta_{6} L M I_{i, t}+\beta_{7} L M O R_{i, t}+\beta_{8} L T_{i, t}+\beta_{9} L T_{i, t} * L O I L_{i, t}+\varepsilon_{i, t}
\end{aligned}
$$

Where $\beta_{0 i}$ is the unobserved, time-invariant individual effect. 


\section{A2.3. Period fixed effect model}

In this study, we also apply period fixed effect model. This model essentially captures all effects that are specific to the periods and do not vary over countries. Macroeconomic variables such as GDP, trade, reserve and capital can vary over time. For example, technological development or international agreements can change productivity growth globally which increases output over time. Period fixed effect model removes the effect of those countryinvariant characteristics so that we can assess the net impact of oil rent on economic growth. We can write equation (1) with fixed effect as follows:

$$
\begin{aligned}
& \triangle L G D P_{i, t}=\beta_{0 t}+\beta_{1} \Delta L G D P_{i, t-1}+\beta_{2} L O I L_{i, t}+\beta_{3} L U N_{i, t}+\beta_{4} L F D I_{i, t}+\beta_{5} L C A B_{i, t}+ \\
& \beta_{6} L M I_{i, t}+\beta_{7} L M O R_{i, t}+\beta_{8} L T_{i, t}+\beta_{9} L T_{i, t} * L O I L_{i, t}+\varepsilon_{i, t}
\end{aligned}
$$

Where $\beta_{0 t}$ is the unobserved, country-invariant individual effect.

\section{A2.4. Cross-section random effect model}

The rationale behind the cross-section random effect model is that, unlike the cross-section fixed effect model, the variation across countries is assumed to be random and uncorrelated with the predictor or independent variables included in the model. For example, in the random effect model it is assumed that an unobserved effect (e.g., geographical factors, natural endowments, political and cultural systems) are not correlated with economic growth. The cross-section random effect model includes all fixed effect assumptions plus the additional requirement that $\left(Q_{i}\right)$ is independent of all explanatory variables in all time periods. Thus, the variability of the constant for each section comes from:

$$
\beta_{0 i}=\beta_{0}+Q_{i}
$$

Where $Q_{i}$ is a zero-mean standard random variable. Therefore, equation (3) with random effect takes the following form: 
$\Delta L G D P_{i, t}=\beta_{0}+\beta_{1} \Delta L G D P_{i, t-1}+\beta_{2} L O I L_{i, t}+\beta_{3} L U N_{i, t}+\beta_{4} L F D I_{i, t}+\beta_{5} L C A B_{i, t}+$

$\beta_{6} L M I_{i, t}+\beta_{7} L M O R_{i, t}+\beta_{8} L T_{i, t}+\beta_{9} L T_{i, t} * L O I L_{i, t}+Q_{i}+\varepsilon_{i, t}$

\section{A2.5. Period random effect model}

This model assumes that variation is arising over time to be random and uncorrelated with the independent variables included in the model. So, we can rewrite equation (7) as:

$\Delta L G D P_{i, t}=\beta_{0}+\beta_{1} \Delta L G D P_{i, t-1}+\beta_{2} L O I L_{i, t}+\beta_{3} L U N_{i, t}+\beta_{4} L F D I_{i, t}+\sum_{i=0}^{n} \beta_{5} L C A B_{i, t}+$

$\beta_{6} L M I_{i, t}+\beta_{7} L M O R_{i, t}+\beta_{8} L T_{i, t}+\beta_{9} L T_{i, t} * L O I L_{i, t}+Q_{t}+\varepsilon_{i, t}$

Where $Q_{t}$ is a zero-mean standard random variable that is independent of all explanatory variables in all countries. 


\section{Appendix 3}

\section{A3. Robustness check}

\section{A3.1. Alternative measures of trade openness}

To check the robustness of the results, we use two alternative measures of trade openness: exports and imports. Tables A6 and A7 represent the empirical findings of the impact of oil rent on economic growth interacting with the two alternative measures of trade openness. From both tables, we find that the coefficient of oil rent is negative and significant, indicating that economic growth decreases with the increase of oil rent. Conversely, the positive coefficient of $\log$ in exports indicates that economic growth increases with the increase of exports. The coefficient of the interaction term between log in export and log in oil rent is positive and significant, indicating that the negative impact of oil rent on economic growth reduces with the increase of exports. The government's total income will increase with the increase in export that increases real GDP per capita. 
Table A6: Change in real GDP per capita and oil rent in terms of export (1980-2017)

\begin{tabular}{|c|c|c|c|c|c|c|}
\hline \multirow{4}{*}{$\Delta L G D P_{i, t-1}$} & \multicolumn{6}{|c|}{ Dependent variable: $\Delta L G D P_{i, t}$} \\
\hline & $\begin{array}{c}\text { Cross-section } \\
\text { and period fixed } \\
(1)\end{array}$ & $\begin{array}{l}\text { PLS } \\
(2) \\
\end{array}$ & $\begin{array}{l}\text { Cross-section } \\
\text { fixed } \\
(3) \\
\end{array}$ & $\begin{array}{l}\text { Cross-section } \\
\text { random } \\
(4)\end{array}$ & $\begin{array}{l}\text { Period } \\
\text { fixed } \\
(5) \\
\end{array}$ & $\begin{array}{l}\text { Period } \\
\text { random } \\
(6)\end{array}$ \\
\hline & $0.40 * * *$ & $0.46^{* * *}$ & $0.36 * * *$ & $0.46^{* * *}$ & $0.51 * * *$ & $0.50 * * *$ \\
\hline & $(0.01)$ & $(0.01)$ & $(0.01)$ & $(0.01)$ & $(0.01)$ & $(0.01)$ \\
\hline \multirow{4}{*}{$L O I L_{i, t}$} & [0.03] & [0.03] & [0.03] & {$[0.03]$} & [0.03] & [0.03] \\
\hline & $-0.03 * * *$ & $-0.01 * *$ & $-0.03 * * *$ & $-0.01 * *$ & $-0.01 * * *$ & $-0.01 * * *$ \\
\hline & $(0.009)$ & $(0.005)$ & $(0.01)$ & $(0.005)$ & $(0.004)$ & $(0.004)$ \\
\hline & {$[0.01]$} & {$[0.008]$} & {$[0.01]$} & [0.008] & {$[0.007]$} & {$[0.007]$} \\
\hline \multirow{3}{*}{$L U N_{i, t}$} & -0.0005 & 0.0008 & -0.0004 & 0.0008 & -0.0001 & -0.0002 \\
\hline & $(0.001)$ & $(0.001)$ & $(0.001)$ & $(0.001)$ & $(0.0009)$ & $(0.0009)$ \\
\hline & {$[0.003]$} & {$[0.001]$} & {$[0.003]$} & {$[0.001]$} & {$[0.001]$} & {$[0.001]$} \\
\hline \multirow[t]{3}{*}{$L F D I_{i, t}$} & -0.003 & 0.002 & 0.004 & 0.002 & -0.003 & -0.003 \\
\hline & $(0.005)$ & $(0.008)$ & $(0.006)$ & $(0.005)$ & $(0.005)$ & $(0.005)$ \\
\hline & {$[0.004]$} & {$[0.004]$} & [0.004] & [0.004] & [0.004] & {$[0.004]$} \\
\hline \multirow{3}{*}{$L C A B_{i, t}$} & $-0.12 * * *$ & $-0.06 * * *$ & $-0.11^{* * *}$ & $-0.06 * * *$ & $-0.07 * * *$ & $-0.07 * * *$ \\
\hline & $(0.03)$ & $(0.02)$ & $(0.03)$ & $(0.02)$ & $(0.02)$ & $(0.02)$ \\
\hline & {$[0.04]$} & [0.03] & [0.05] & [0.03] & [0.03] & [0.03] \\
\hline \multirow{3}{*}{$L M I_{i, t}$} & $-0.01 * * *$ & $-0.002^{*}$ & $-0.01 * * *$ & $-0.002 *$ & -0.001 & -0.001 \\
\hline & $(0.003)$ & $(0.001)$ & $(0.003)$ & $(0.001)$ & $(0.001)$ & $(0.001)$ \\
\hline & {$[0.004]$} & {$[0.001]$} & {$[0.004]$} & {$[0.001]$} & {$[0.001]$} & {$[0.001]$} \\
\hline \multirow[t]{3}{*}{$L M O R_{i, t}$} & $0.01 * * *$ & $0.002 * * *$ & $0.01 * * *$ & $0.002 * * *$ & $0.001 * *$ & $0.001 * *$ \\
\hline & $(0.004)$ & $(0.0008)$ & $(0.002)$ & $(0.0008)$ & $(0.0008)$ & $(0.0008)$ \\
\hline & {$[0.004]$} & {$[0.001]$} & [0.002] & {$[0.001]$} & [0.0009] & [0.0009] \\
\hline \multirow[t]{3}{*}{$L E X_{i, t}$} & 0.004 & $0.003^{* *}$ & $0.009 * *$ & $0.003 * *$ & $0.002 * *$ & $0.002 * *$ \\
\hline & $(0.003)$ & $(0.001)$ & $(0.003)$ & $(0.001)$ & $(0.001)$ & $(0.001)$ \\
\hline & [0.004] & {$[0.001]$} & {$[0.004]$} & [0.001] & {$[0.001]$} & {$[0.001]$} \\
\hline \multirow[t]{3}{*}{$L E X_{i, t} * L^{\prime O I L} L_{i, t}$} & $0.01 * * *$ & $0.004 * * *$ & $0.01 * * *$ & $0.004^{* * *}$ & $0.003 * * *$ & $0.003^{* * *}$ \\
\hline & $(0.002)$ & $(0.001)$ & $(0.002)$ & $(0.001)$ & $(0.001)$ & $(0.001)$ \\
\hline & {$[0.003]$} & [0.002] & {$[0.004]$} & [0.002] & {$[0.002]$} & {$[0.002]$} \\
\hline $\mathrm{R}^{2}$ & 0.47 & 0.26 & 0.33 & 0.26 & 0.42 & 0.30 \\
\hline Adjusted $\mathrm{R}^{2}$ & 0.44 & 0.26 & 0.30 & 0.26 & 0.41 & 0.30 \\
\hline Periods & 38 & 38 & 38 & 38 & 38 & 38 \\
\hline Countries & 95 & 95 & 95 & 95 & 95 & 95 \\
\hline Observations & 2,499 & 2,499 & 2,499 & 2,499 & 2,499 & 2,499 \\
\hline
\end{tabular}

Note: $L E X_{i, t}$ indicates log in exports (\% of GDP). Standard errors are presented below the corresponding coefficients in the bracket. $* * *, * *$ and $*$ indicate the significance at the $10 \%, 5 \%$, and $1 \%$ level respectively. Cluster standard errors are presented in square brackets.

We observe a similar pattern in results when we look at Table A7, where we use imports as an alternative measure of trade openness. Economic growth increases with the increase of imports and the negative impact of oil rent on economic growth decreases with the increase of imports. A country can hire new technologies and high-tech products by allowing import 
openness. Moreover, import helps to increase efficiency in the managerial level by exchanging advanced knowledge between economies.

Table A7: Change in real GDP per capita and oil rent in terms of import (1980-2017)

\begin{tabular}{|c|c|c|c|c|c|c|}
\hline & \multicolumn{6}{|c|}{ Dependent variable: $\Delta L G D P_{i, t}$} \\
\hline & $\begin{array}{c}\text { Cross-section } \\
\text { and period fixed } \\
(1)\end{array}$ & $\begin{array}{l}\text { PLS } \\
(2) \\
\end{array}$ & $\begin{array}{c}\text { Cross-section } \\
\text { fixed } \\
(3) \\
\end{array}$ & $\begin{array}{l}\text { Cross-section } \\
\text { random } \\
(4) \\
\end{array}$ & $\begin{array}{l}\text { Period } \\
\text { fixed } \\
(5) \\
\end{array}$ & $\begin{array}{l}\text { Period } \\
\text { random } \\
(6)\end{array}$ \\
\hline \multirow{3}{*}{$\Delta L G D P_{i, t-1}$} & $0.41 * * *$ & $0.46 * * *$ & $0.36^{* * *}$ & $0.46^{* * *}$ & $0.51 * * *$ & $0.50 * * *$ \\
\hline & $(0.01)$ & $(0.01)$ & $(0.01)$ & $(0.01)$ & $(0.01)$ & $(0.01)$ \\
\hline & {$[0.03]$} & [0.03] & [0.03] & {$[0.03]$} & {$[0.03]$} & {$[0.03]$} \\
\hline \multirow{3}{*}{$L O I L_{i, t}$} & $-0.02 * * *$ & $-0.01 * *$ & $-0.02 * *$ & $-0.01 * *$ & $-0.01 * * *$ & $-0.01 * * *$ \\
\hline & $(0.009)$ & $(0.006)$ & $(0.01)$ & $(0.006)$ & $(0.005)$ & $(0.005)$ \\
\hline & {$[0.01]$} & {$[0.007]$} & {$[0.01]$} & {$[0.007]$} & [0.006] & {$[0.006]$} \\
\hline \multirow[t]{3}{*}{$L U N_{i, t}$} & -0.0006 & 0.0008 & -0.0005 & 0.0008 & -0.0002 & -0.0003 \\
\hline & $(0.001)$ & $(0.001)$ & $(0.001)$ & $(0.001)$ & $(0.0009)$ & $(0.0009)$ \\
\hline & {$[0.003]$} & {$[0.001]$} & {$[0.003]$} & {$[0.001]$} & {$[0.001]$} & {$[0.001]$} \\
\hline \multirow[t]{3}{*}{$L F D I_{i, t}$} & -0.002 & 0.002 & 0.005 & 0.002 & -0.003 & -0.003 \\
\hline & $(0.005)$ & $(0.005)$ & $(0.006)$ & $(0.005)$ & (0.005) & $(0.005)$ \\
\hline & {$[0.004]$} & {$[0.004]$} & {$[0.003]$} & {$[0.004]$} & [0.004] & {$[0.004]$} \\
\hline \multirow[t]{3}{*}{$L C A B_{i, t}$} & -0.02 & -0.01 & 0.01 & -0.01 & -0.03 & -0.03 \\
\hline & $(0.03)$ & $(0.02)$ & $(0.03)$ & $(0.02)$ & $(0.02)$ & $(0.02)$ \\
\hline & {$[0.05]$} & [0.03] & [0.05] & [0.03] & [0.03] & [0.03] \\
\hline \multirow[t]{3}{*}{$L M I_{i, t}$} & $-0.01 * * *$ & $-0.002 *$ & $-0.02 * * *$ & $-0.002 *$ & -0.001 & -0.001 \\
\hline & $(0.03)$ & $(0.001)$ & $(0.003)$ & $(0.001)$ & $(0.001)$ & $(0.001)$ \\
\hline & {$[0.004]$} & [0.001] & [0.005] & {$[0.001]$} & {$[0.001]$} & {$[0.001]$} \\
\hline \multirow[t]{3}{*}{$L M O R_{i, t}$} & $0.01 * * *$ & $-0.002 * * *$ & $0.01 * * *$ & $-0.002 * * *$ & $0.001 * *$ & $0.001 * *$ \\
\hline & $(0.004)$ & $(0.0008)$ & $(0.002)$ & $(0.0008)$ & (0.0008) & $(0.0008)$ \\
\hline & [0.004] & {$[0.001]$} & {$[0.002]$} & {$[0.001]$} & [0.0009] & [0.0009] \\
\hline \multirow[t]{3}{*}{$L I M_{i, t}$} & $0.007 * *$ & $0.003^{* * *}$ & $0.01 * * *$ & $0.003 * * *$ & $0.002 * *$ & $0.002 * *$ \\
\hline & $(0.003)$ & $(0.001)$ & $(0.004)$ & $(0.001)$ & $(0.001)$ & $(0.001)$ \\
\hline & {$[0.006]$} & {$[0.001]$} & {$[0.006]$} & {$[0.001]$} & {$[0.001]$} & {$[0.001]$} \\
\hline \multirow{3}{*}{$\operatorname{LIM}_{i, t} * L O I L_{i, t}$} & $0.008 * * *$ & $0.005^{* * *}$ & $0.009 * * *$ & $0.005^{* * *}$ & $0.004 * * *$ & $0.004 * * *$ \\
\hline & $(0.002)$ & $(0.001)$ & $(0.002)$ & $(0.001)$ & $(0.001)$ & $(0.001)$ \\
\hline & [0.003] & [0.002] & [0.003] & [0.002] & {$[0.001]$} & {$[0.001]$} \\
\hline $\mathrm{R}^{2}$ & 0.47 & 0.26 & 0.32 & 0.26 & 0.42 & 0.30 \\
\hline Adjusted $\mathrm{R}^{2}$ & 0.44 & 0.26 & 0.30 & 0.25 & 0.41 & 0.30 \\
\hline Periods & 38 & 38 & 38 & 38 & 38 & 38 \\
\hline Countries & 95 & 95 & 95 & 95 & 95 & 95 \\
\hline Observations & 2,499 & 2,499 & 2,499 & 2,499 & 2,499 & 2,499 \\
\hline
\end{tabular}

Note: $L I M_{i, t}$ indicates log in imports (\% of GDP). Standard errors are presented below the corresponding coefficients in the bracket. $* * *, * *$ and $*$ indicate the significance at the $10 \%, 5 \%$, and $1 \%$ level respectively. Cluster standard errors are presented in square brackets. 


\section{A3.2. Alternative measures of resource abundance}

We use natural resource rent instead of oil rent to check the resource curse hypothesis and the impact of trade openness on economic growth. Table A8 presents the empirical findings of the nexus between natural resource rent and economic growth interacting with trade openness with different dynamic panel data models. The coefficient of natural resource rent is negative, indicating that economic growth decreases with the increase of natural resource rent and the estimated elasticity is -0.05 . All other things being equal, a one per cent increase in natural resource rents is associated with a significant decrease in the economic growth of over 0.05 per cent. This negative association between economic growth and natural resource rents provides evidence of the resource curse.

The coefficient of the interaction term between trade openness and natural resource rent is also positive, indicating that a more open trade regime lessens the negative impact of natural resource rent on economic growth. These results are significant $(p=0.01)$ and consistent with different time and country fixed effect and random effect models. Tables A9 and A10 show the impact of natural resource rent on economic growth in terms of exports and imports and find that both export and import reduce the resource course. 
Table A8: Change in real GDP per capita and natural resource rent in terms of trade openness (1980-2017)

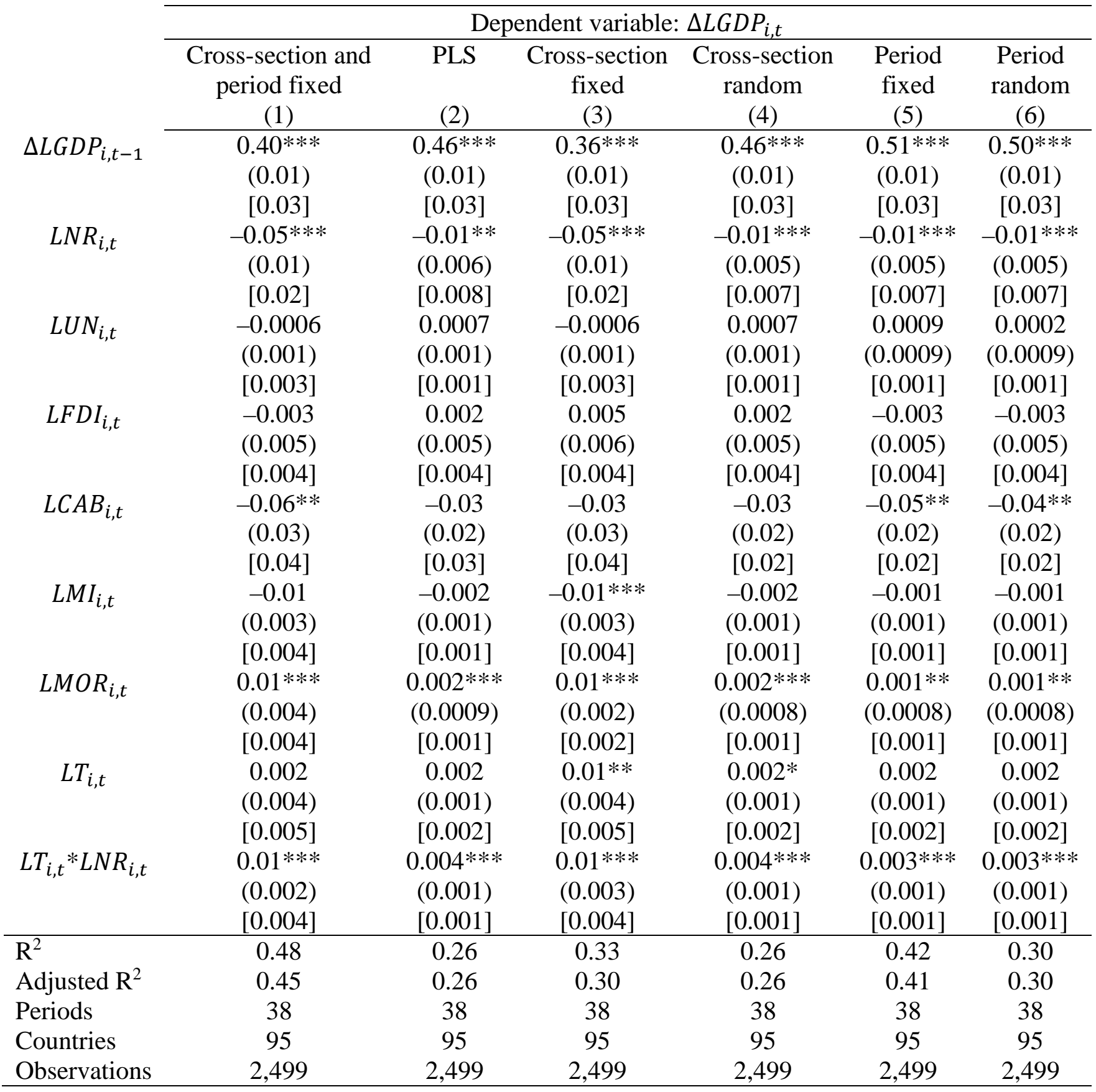

Note: $L N R_{i, t}$ indicates log in natural resource rent (\% of GDP). Standard errors are presented below the corresponding coefficients in the bracket. ${ }^{* * *},{ }^{* *}$ and $*$ indicate the significance at the $10 \%, 5 \%$, and $1 \%$ level respectively. Cluster standard errors are presented in square brackets. 
Table A9: Change in real GDP per capita and natural resource rent in terms of export (19802017)

\begin{tabular}{|c|c|c|c|c|c|c|}
\hline \multirow{4}{*}{$\Delta L G D P_{i, t-1}$} & \multicolumn{6}{|c|}{ Dependent variable: $\Delta L G D P_{i, t}$} \\
\hline & \multirow[t]{2}{*}{$\begin{array}{c}\text { Cross-section } \\
\text { and period fixed } \\
(1) \\
0.40 * * *\end{array}$} & $\begin{array}{l}\text { PLS } \\
\text { (2) }\end{array}$ & $\begin{array}{l}\text { Cross-section } \\
\text { Fixed } \\
(3) \\
\end{array}$ & $\begin{array}{l}\text { Cross-section } \\
\text { Random } \\
(4)\end{array}$ & $\begin{array}{l}\text { Period } \\
\text { fixed } \\
(5)\end{array}$ & $\begin{array}{l}\text { Period } \\
\text { random } \\
(6)\end{array}$ \\
\hline & & $0.46^{* * *}$ & $0.36^{* * *}$ & $0.46^{* * *}$ & $0.51 * * *$ & $0.50 * * *$ \\
\hline & $(0.01)$ & $(0.01)$ & $(0.01)$ & $(0.01)$ & $(0.01)$ & $(0.01)$ \\
\hline & {$[0.03]$} & {$[0.03]$} & {$[0.03]$} & {$[0.03]$} & {$[0.03]$} & {$[0.03]$} \\
\hline \multirow{3}{*}{$L N R_{i, t}$} & $-0.04 * * *$ & $-0.01 * *$ & $-0.04 * * *$ & $-0.01 * *$ & $-0.01 * * *$ & $-0.01 * * *$ \\
\hline & $(0.009)$ & $(0.004)$ & $(0.01)$ & $(0.004)$ & $(0.004)$ & $(0.004)$ \\
\hline & {$[0.01]$} & {$[0.007]$} & {$[0.01]$} & {$[0.007]$} & {$[0.006]$} & {$[0.006]$} \\
\hline \multirow{3}{*}{$L U N_{i, t}$} & -0.0003 & 0.0007 & -0.0002 & 0.0007 & 0.0001 & 0.0002 \\
\hline & $(0.0009)$ & $(0.001)$ & $(0.001)$ & $(0.001)$ & $(0.0009)$ & $(0.0009)$ \\
\hline & [0.003] & [0.001] & {$[0.003]$} & {$[0.001]$} & {$[0.001]$} & {$[0.001]$} \\
\hline \multirow[t]{3}{*}{$L F D I_{i, t}$} & -0.003 & 0.002 & 0.004 & 0.002 & -0.003 & -0.003 \\
\hline & $(0.005)$ & $(0.005)$ & $(0.006)$ & $(0.005)$ & $(0.005)$ & $(0.005)$ \\
\hline & {$[0.004]$} & [0.004] & {$[0.004]$} & {$[0.004]$} & {$[0.004]$} & {$[0.004]$} \\
\hline \multirow{3}{*}{$L C A B_{i, t}$} & $-0.12 * * *$ & -0.06 & $-0.11^{* * *}$ & -0.06 & $-0.07 * * *$ & $-0.07 * * *$ \\
\hline & $(0.03)$ & $(0.02)$ & $(0.03)$ & $(0.02)$ & $(0.02)$ & $(0.02)$ \\
\hline & {$[0.04]$} & [0.03] & {$[0.05]$} & {$[0.03]$} & [0.03] & [0.03] \\
\hline \multirow[t]{3}{*}{$L M I_{i, t}$} & -0.01 & -0.002 & $-0.01 * * *$ & -0.002 & -0.001 & -0.001 \\
\hline & $(0.003)$ & $(0.001)$ & $(0.003)$ & $(0.001)$ & $(0.001)$ & $(0.001)$ \\
\hline & [0.004] & {$[0.001]$} & [0.004] & {$[0.001]$} & {$[0.001]$} & {$[0.001]$} \\
\hline \multirow[t]{3}{*}{$L M O R_{i, t}$} & $0.01 * *$ & $0.002 * * *$ & $0.01 * * *$ & $0.002 * * *$ & $0.001^{* *}$ & $0.001 * *$ \\
\hline & $(0.004)$ & $(0.0009)$ & $(0.002)$ & $(0.0008)$ & (0.0008) & $(0.0008)$ \\
\hline & [0.004] & {$[0.001]$} & {$[0.002]$} & {$[0.001]$} & {$[0.001]$} & {$[0.001]$} \\
\hline \multirow[t]{3}{*}{$L E X_{i, t}$} & -0.002 & 0.002 & 0.002 & 0.002 & 0.001 & 0.001 \\
\hline & $(0.003)$ & $(0.001)$ & $(0.004)$ & $(0.001)$ & $(0.001)$ & $(0.001)$ \\
\hline & {$[0.005]$} & {$[0.002]$} & {$[0.005]$} & {$[0.002]$} & {$[0.001]$} & {$[0.002]$} \\
\hline \multirow{3}{*}{$L E X_{i, t} * L N R_{i, t}$} & $0.01 * * *$ & $0.004^{* * *}$ & $0.01 * * *$ & $0.004^{* * *}$ & $0.003 * * *$ & $0.003^{* * *}$ \\
\hline & $(0.002)$ & $(0.001)$ & $(0.002)$ & $(0.001)$ & $(0.001)$ & $(0.001)$ \\
\hline & {$[0.004]$} & {$[0.002]$} & {$[0.002]$} & {$[0.002]$} & {$[0.001]$} & {$[0.001]$} \\
\hline $\mathrm{R}^{2}$ & 0.48 & 0.26 & 0.33 & 0.26 & 0.42 & 0.30 \\
\hline Adjusted $\mathrm{R}^{2}$ & 0.48 & 0.26 & 0.30 & 0.26 & 0.41 & 0.30 \\
\hline Periods & 38 & 38 & 38 & 38 & 38 & 38 \\
\hline Countries & 95 & 95 & 95 & 95 & 95 & 95 \\
\hline Observations & 2499 & 2499 & 2499 & 2499 & 2499 & 2499 \\
\hline
\end{tabular}


Table A10: Change in real GDP per capita and natural resource rent in terms of import (1980-2017)

\begin{tabular}{|c|c|c|c|c|c|c|}
\hline & \multicolumn{6}{|c|}{ Dependent variable: $\Delta L G D P_{i, t}$} \\
\hline \multirow{4}{*}{$\Delta L G D P_{i, t-1}$} & $\begin{array}{c}\text { Cross-section } \\
\text { and period fixed } \\
(1)\end{array}$ & $\begin{array}{l}\text { PLS } \\
(2)\end{array}$ & $\begin{array}{l}\text { Cross-section } \\
\text { Fixed } \\
\text { (3) }\end{array}$ & $\begin{array}{l}\text { Cross-section } \\
\text { Random } \\
\text { (4) }\end{array}$ & $\begin{array}{l}\text { Period } \\
\text { fixed } \\
(5)\end{array}$ & $\begin{array}{l}\text { Period } \\
\text { random } \\
(6)\end{array}$ \\
\hline & $0.41 * * *$ & $0.46 * * *$ & $0.36 * * *$ & $0.46 * * *$ & $0.51 * * *$ & $0.50 * * *$ \\
\hline & $(0.01)$ & $(0.01)$ & $(0.01)$ & $(0.01)$ & $(0.01)$ & $(0.01)$ \\
\hline & {$[0.03]$} & [0.03] & [0.03] & [0.03] & [0.03] & [0.03] \\
\hline \multirow{3}{*}{$L N R_{i, t}$} & $-0.02 * * *$ & $-0.01 * *$ & $-0.02 * *$ & $-0.01 * *$ & $-0.01 * * *$ & $-0.01 * * *$ \\
\hline & $(0.009)$ & $(0.005)$ & $(0.01)$ & $(0.005)$ & $(0.004)$ & $(0.004)$ \\
\hline & {$[0.01]$} & {$[0.005]$} & {$[0.01]$} & {$[0.005]$} & [0.005] & {$[0.005]$} \\
\hline \multirow[t]{3}{*}{$L U N_{i, t}$} & -0.0005 & 0.0006 & -0.0002 & 0.0006 & 0.0003 & 0.0001 \\
\hline & $(0.001)$ & $(0.001)$ & $(0.002)$ & $(0.001)$ & $(0.0009)$ & $(0.0009)$ \\
\hline & {$[0.002]$} & [0.001] & {$[0.003]$} & [0.001] & {$[0.001]$} & {$[0.001]$} \\
\hline \multirow[t]{3}{*}{$L F D I_{i, t}$} & -0.002 & 0.002 & 0.005 & 0.002 & -0.003 & -0.003 \\
\hline & $(0.005)$ & $(0.005)$ & $(0.006)$ & $(0.005)$ & $(0.005)$ & $(0.005)$ \\
\hline & [0.004] & [0.004] & [0.004] & [0.004] & [0.004] & [0.004] \\
\hline \multirow{3}{*}{$L C A B_{i, t}$} & $-0.01 * * *$ & -0.003 & -0.03 & -0.003 & -0.02 & -0.02 \\
\hline & $(0.03)$ & $(0.02)$ & $(0.03)$ & $(0.02)$ & $(0.02)$ & $(0.02)$ \\
\hline & [0.05] & [0.03] & [0.05] & [0.03] & [0.03] & [0.03] \\
\hline \multirow[t]{3}{*}{$L M I_{i, t}$} & $-0.01 * * *$ & $-0.002 *$ & $-0.01^{* * *}$ & $-0.002 *$ & -0.001 & -0.001 \\
\hline & $(0.003)$ & $(0.001)$ & $(0.003)$ & $(0.001)$ & $(0.001)$ & $(0.001)$ \\
\hline & [0.004] & {$[0.001]$} & [0.002] & {$[0.001]$} & {$[0.001]$} & {$[0.001]$} \\
\hline \multirow[t]{3}{*}{$L M O R_{i, t}$} & $0.01^{* *}$ & $0.002 * * *$ & $0.01 * * *$ & $0.002 * * *$ & $0.001^{*}$ & $0.001 *$ \\
\hline & $(0.004)$ & $(0.0009)$ & $(0.005)$ & $(0.0008)$ & (0.0008) & (0.0008) \\
\hline & {$[0.005]$} & {$[0.001]$} & {$[0.002]$} & {$[0.001]$} & {$[0.001]$} & {$[0.001]$} \\
\hline \multirow[t]{3}{*}{$L I M_{i, t}$} & 0.002 & $0.003^{*}$ & 0.01 & $0.003^{*}$ & 0.002 & 0.002 \\
\hline & $(0.004)$ & $(0.001)$ & $(0.004)$ & $(0.001)$ & $(0.001)$ & $(0.001)$ \\
\hline & {$[0.007]$} & {$[0.002]$} & {$[0.007]$} & [0.002] & [0.002] & [0.002] \\
\hline \multirow{3}{*}{$L I M_{i, t} * L N R_{i, t}$} & $0.008 * * *$ & $0.003^{* * *}$ & $0.01 * * *$ & $0.003 * * *$ & $0.003 * * *$ & $0.003 * * *$ \\
\hline & $(0.002)$ & $(0.001)$ & $(0.002)$ & $(0.001)$ & $(0.001)$ & $(0.001)$ \\
\hline & {$[0.003]$} & {$[0.001]$} & [0.003] & {$[0.001]$} & {$[0.001]$} & {$[0.001]$} \\
\hline $\mathrm{R}^{2}$ & 0.47 & 0.26 & 0.32 & 0.26 & 0.42 & 0.30 \\
\hline Adjusted $\mathrm{R}^{2}$ & 0.44 & 0.26 & 0.29 & 0.26 & 0.41 & 0.30 \\
\hline Periods & 38 & 38 & 38 & 38 & 38 & 38 \\
\hline Countries & 95 & 95 & 95 & 95 & 95 & 95 \\
\hline Observations & 2499 & 2499 & 2499 & 2499 & 2499 & 2499 \\
\hline
\end{tabular}




\section{Appendix 4}

In figures A1.a., A1.b., and A1.c., we present the marginal effect of oil rent on economic growth in terms of exports for full sample period, and subsample periods 1980-1994 and 19952017 respectively.

Figure A1.a: Marginal effect of oil rent on economic growth (1980-2017)

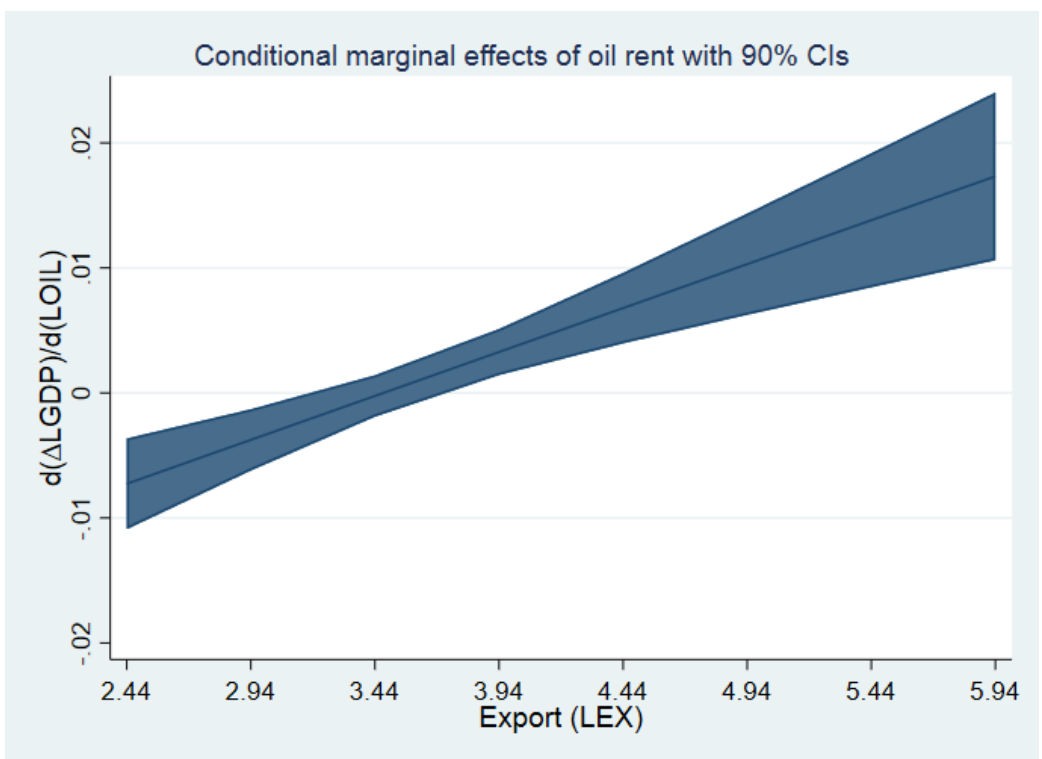

Figure A1.b: Sample period 1980-1994

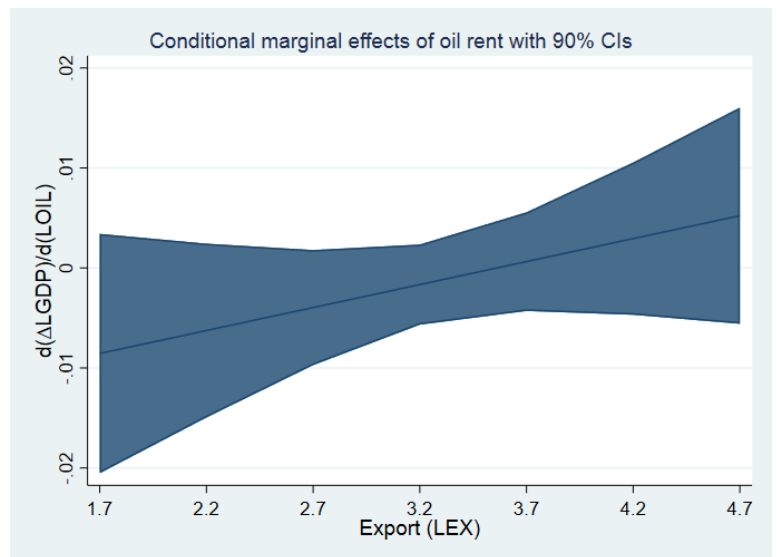

Figure A1.c: Sample period 1995-2017

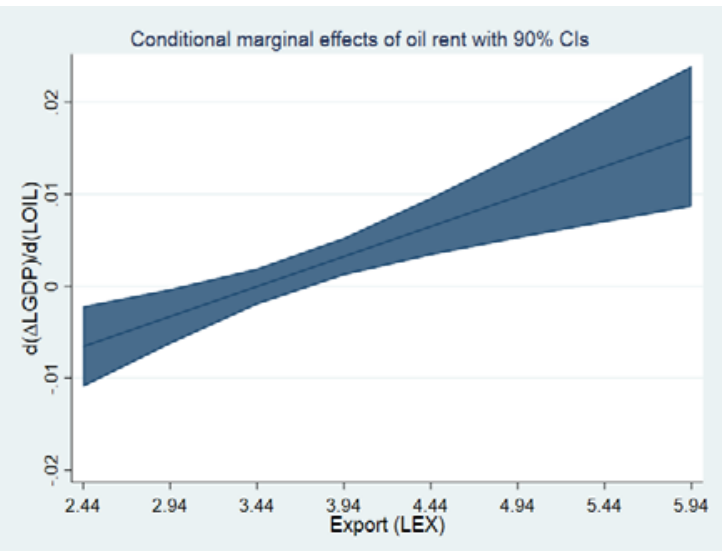


In figures A2.a., A2.b., and A2.c., we present the marginal effect of oil rent on economic growth in terms of imports for full sample period, and subsample periods 1980-1994 and 19952017 respectively.

Figure A2.a: Marginal effect of oil rent on economic growth (1980-2017)

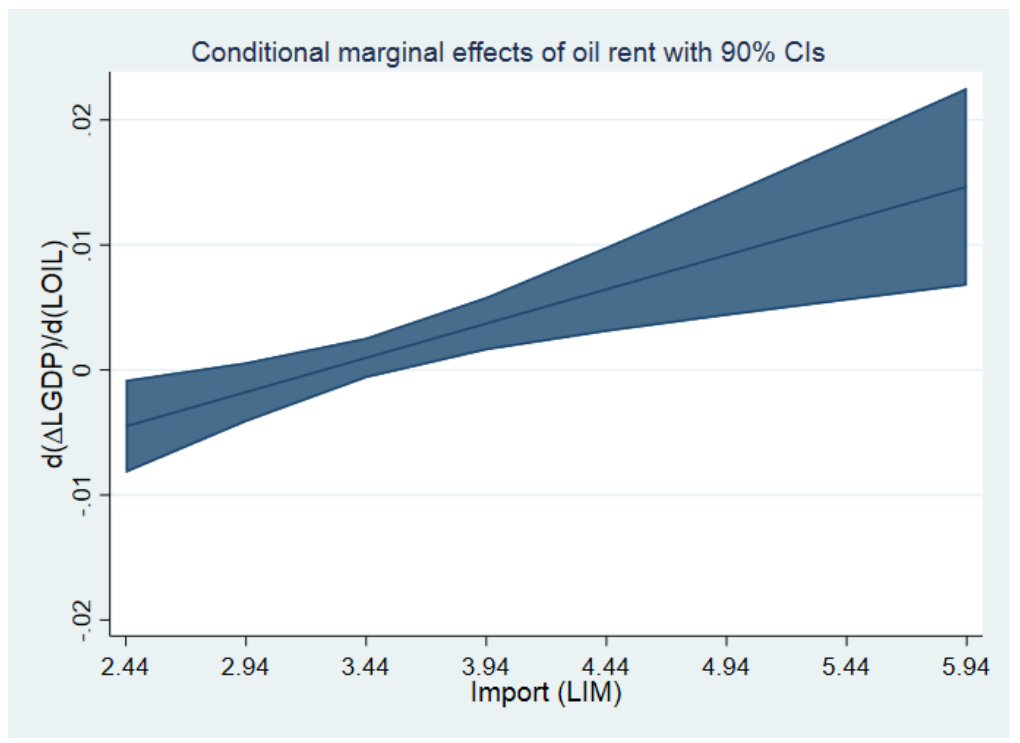

Figure A2.b: Sample period 1980-1994

Figure A2.c: Sample period 1995-2017
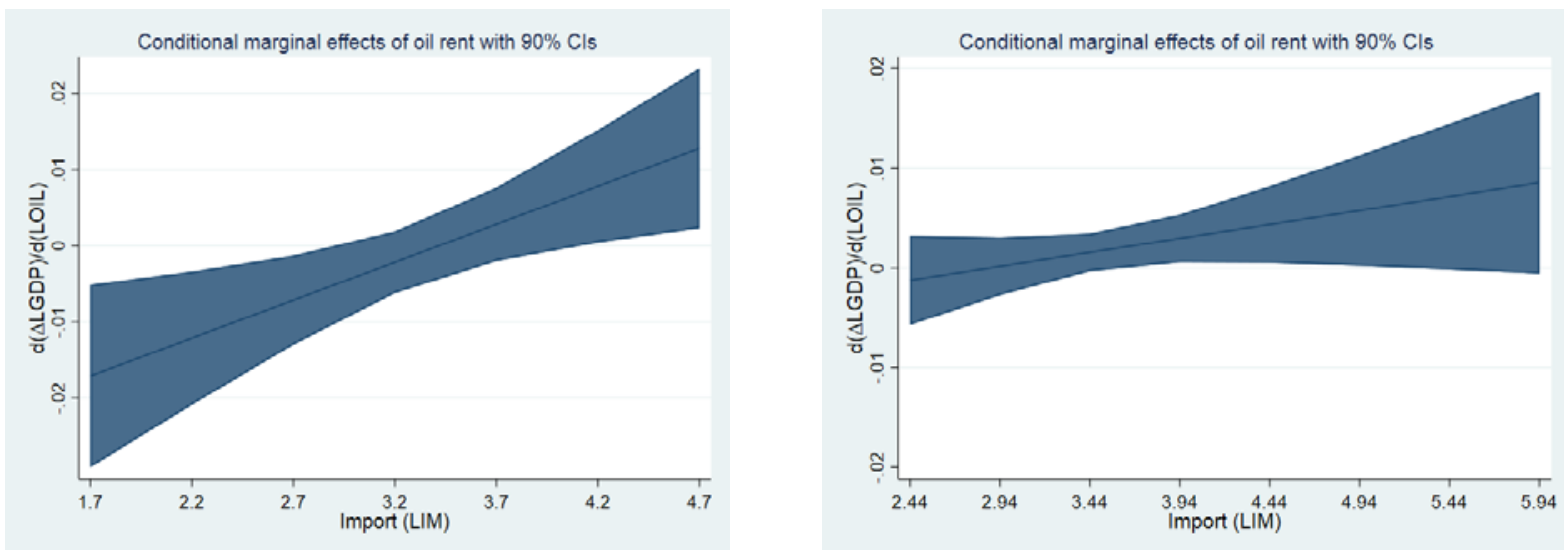
In figures A3.a., A3.b., and A3.c., we present the marginal effect of natural resource rent on economic growth in terms of trade openness for full sample period, and subsample periods 1980-1994 and 1995-2017 respectively.

Figure A3.a: Marginal effect of natural resource rent on economic growth (1980-2017)

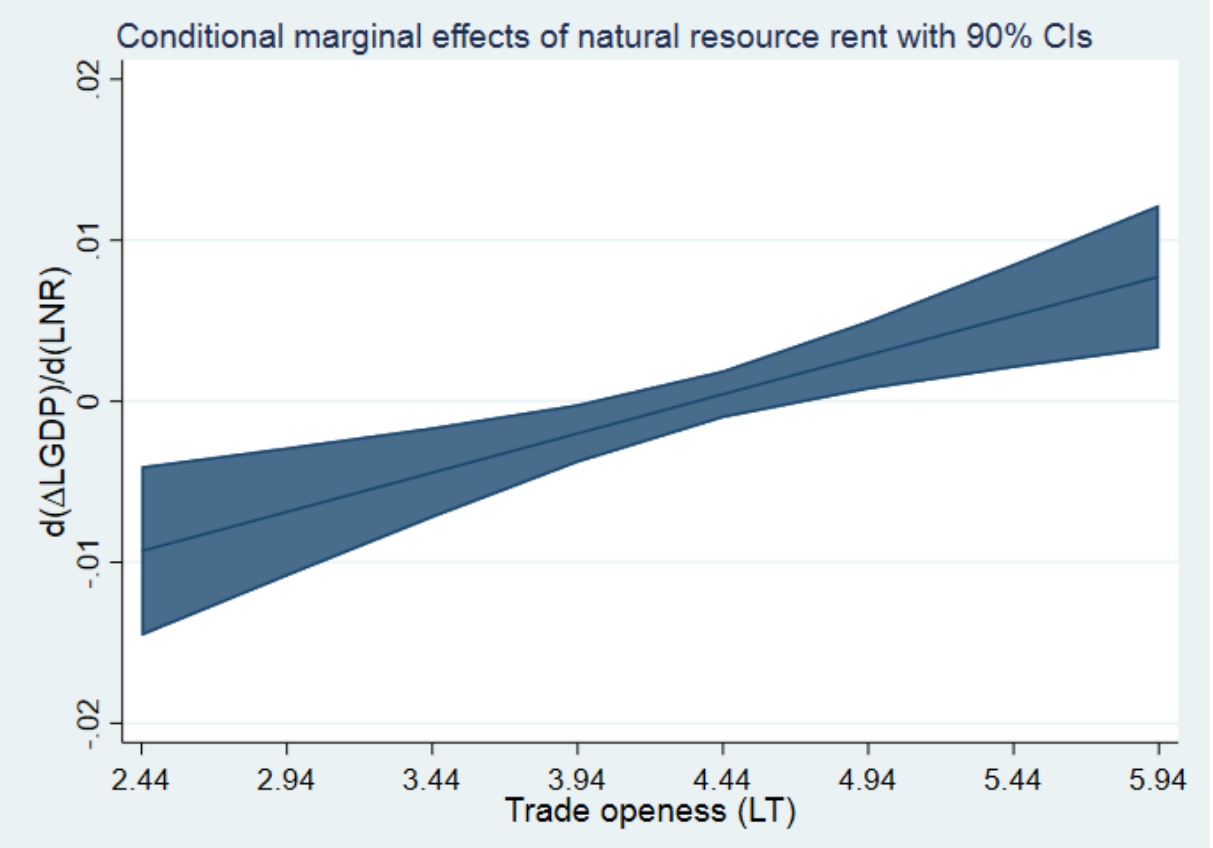

Figure A3.b: Sample period 1980-1994

Figure A3.c: Sample period 1995-2017
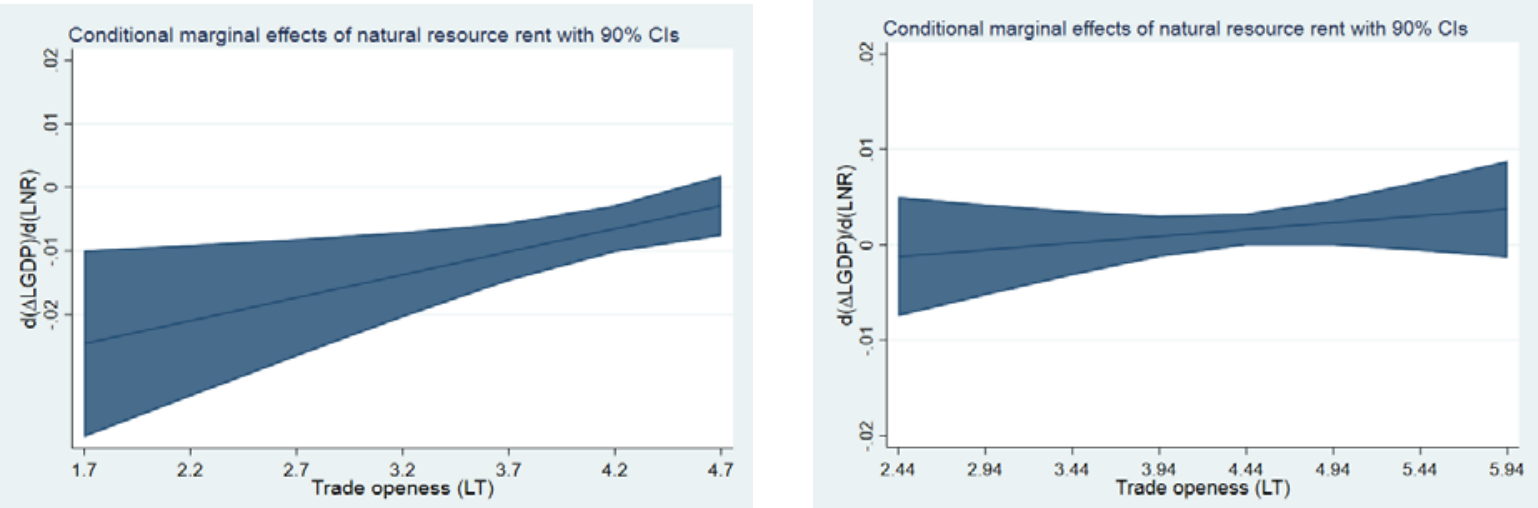
In figures A4.a., A4.b., and A4.c., we present the marginal effect of natural resource rent on economic growth in terms of exports for full sample period, and subsample periods 1980-1994 and 1995-2017 respectively.

Figure A4.a: Marginal effect of natural resource rent on economic growth (1980-2017)

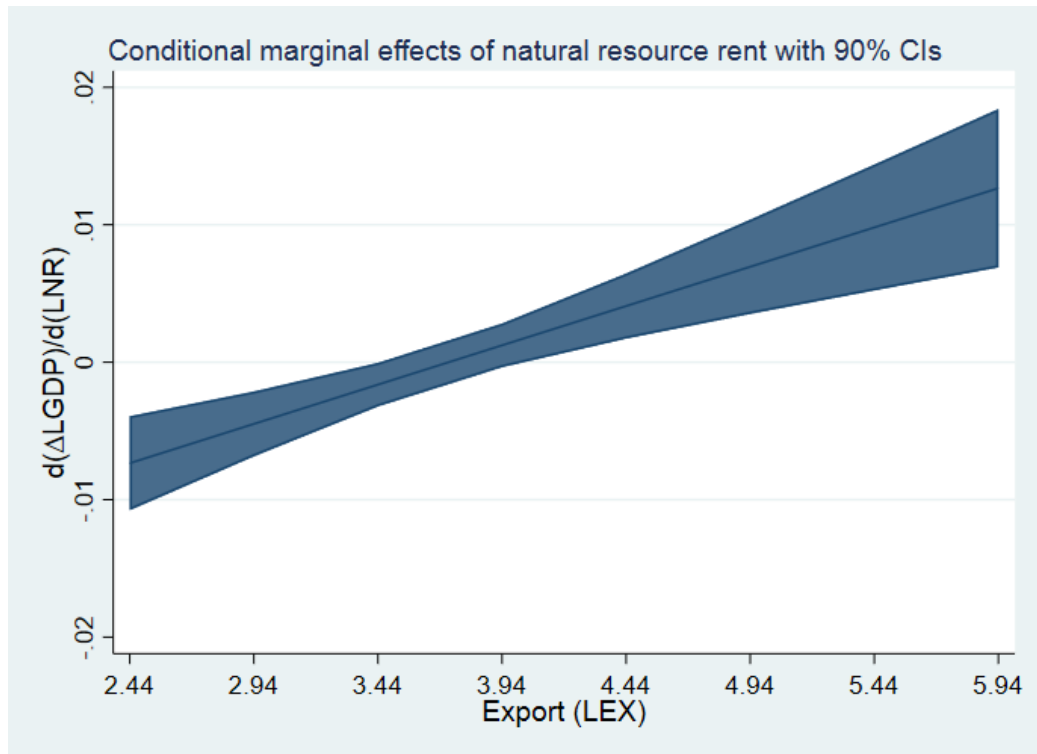

Figure A4.b: Sample period 1980-1994

Figure A4.c: Sample period 1995-2017
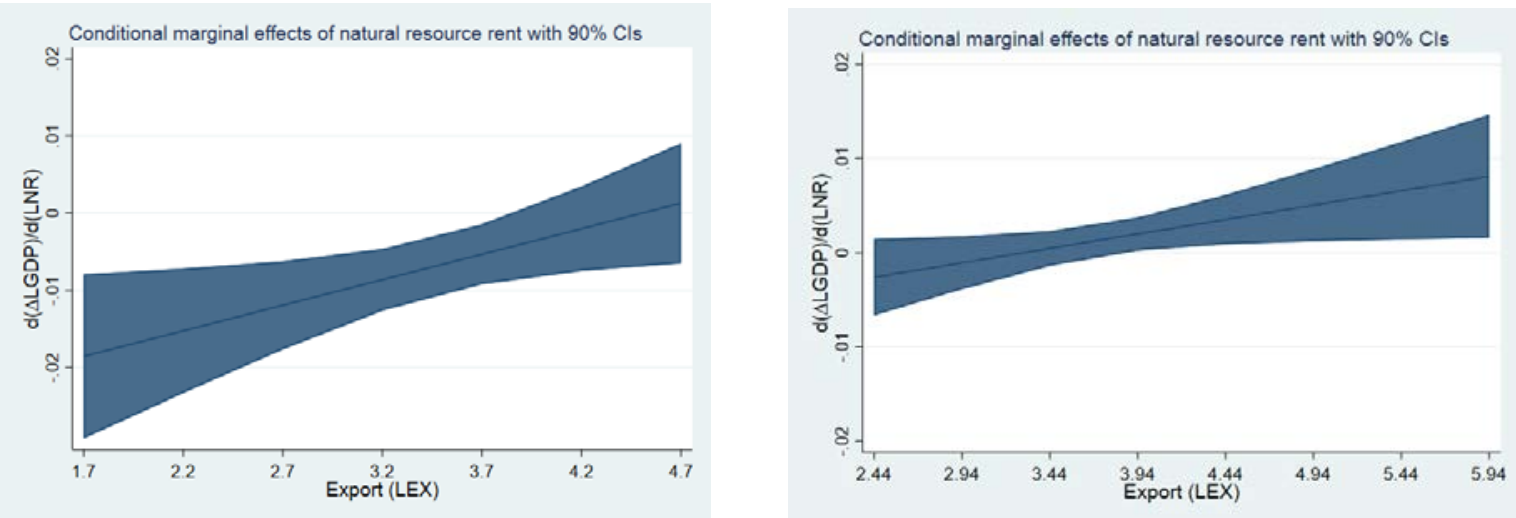
In figures A5.a., A5.b., and A5.c., we present the marginal effect of natural resource rent on economic growth in terms of imports for full sample period, and subsample periods 1980-1994 and 1995-2017 respectively.

Figure A5.a: Marginal effect of natural resource rent on economic growth (1980-2017)

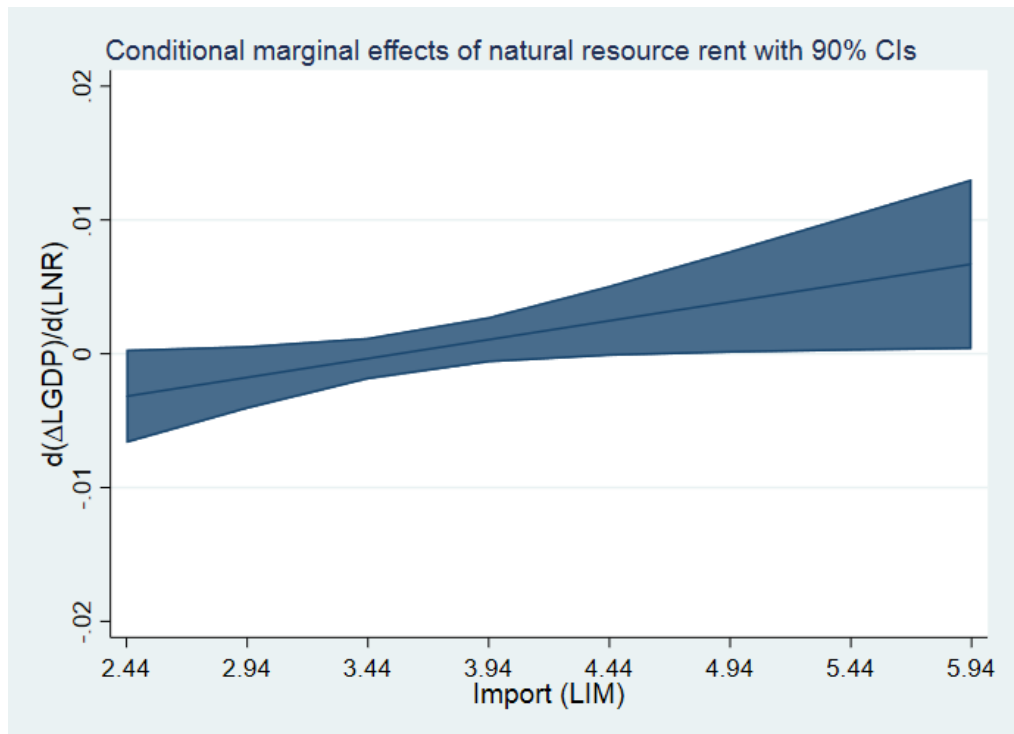

Figure A5.b: Sample period 1980-1994

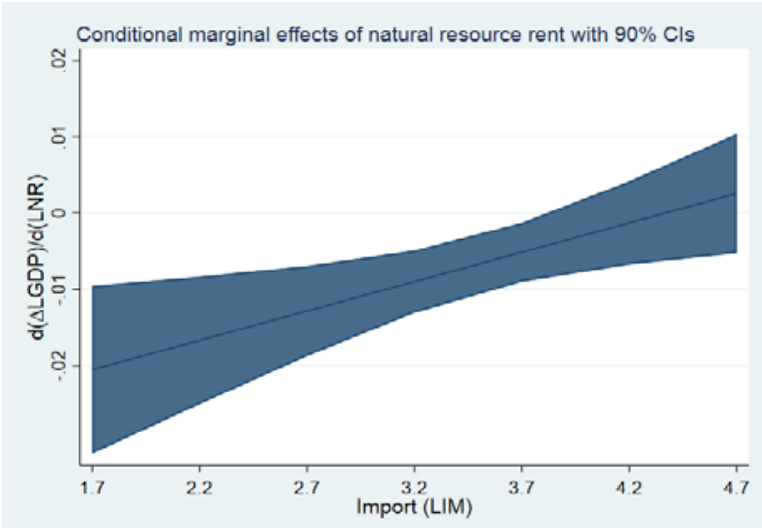

Figure A5.c: Sample period 1995-2017

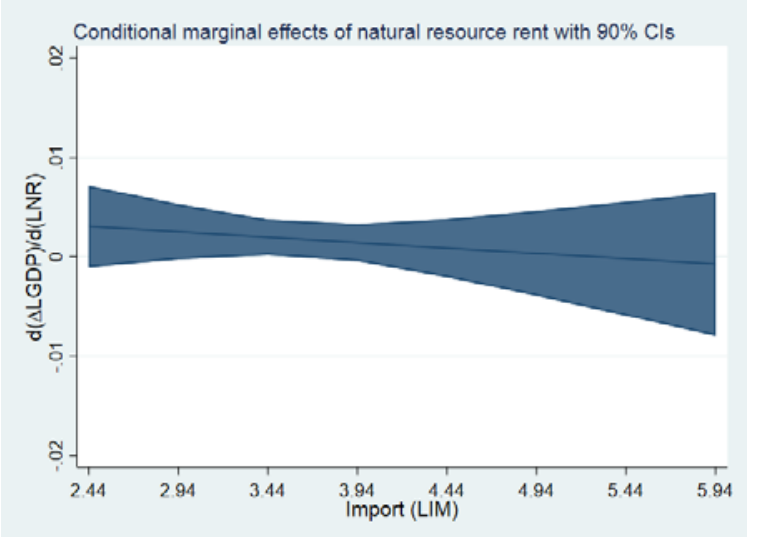

